\title{
Joyería y orfebrería en el Antiguo Testamento
}

\section{INTRODUCCIÓN}

Los metales nobles y las piedras preciosas ocupan un lugar protagonista en la vida social y económica referida en el Antiguo Testamento. Intentar abarcar el tema supone no sólo adentrarnos en un amplísimo periodo temporal, remontándonos desde el cambio de Era, a la Edad del Bronce, a mediados del segundo milenio a.C. (por no ir más allá de la época de los Patriarcas y la llegada de grupos de semitas a Palestina), sino también conocer la orfebrería de Mesopotamia, Babilonia, Egipto, Chipre, Fenicia, Siria, el Imperio Hittita, Persia o Grecia y las relaciones de estos pueblos con el israelita. Además, habrá que hablar de religiones, de magia, de costumbres sociales y políticas, de comercio, alianzas y economía, de tributos, de guerras... También deberemos tener siempre en cuenta que nos encontramos en el Mundo Antiguo, donde la orfebrería y joyería cumplían amplias funciones, no sólo sociales sino también económicas, supliendo la ausencia de moneda en los primeros tiempos o paliando su todavía escasa circulación ${ }^{1}$.

Aquellos grupos de pastores nómadas y seminómadas que acechaban los límites de Mesopotamia y terminaron por asentarse junto a la franja costera del Mediterráneo oriental, un área clave de las comunicaciones de la Antigüedad entre unos y otros imperios, conocían muy bien la riqueza, ostentación y magnificencia de los pueblos vecinos, ocupándose, con frecuencia, del transporte y comercio de sus mercancías. Su admiración y deslumbramiento fue tal que, aun hoy, las palabras joya y judío están indefectiblemente asociadas en el amplísimo ámbito de difusión de la culturas judía y occidental. El amor y el ansia que tanto Yahveh como el pueblo escogido sienten por los metales nobles y las piedras preciosas han quedado tan bien documentados en el texto sagrado que tratar de recoger todas las referencias implicaría reproducirlo prácticamente entero ${ }^{2}$.

1 Pierre VILAR, Oro y moneda en la historia 1450-1920. (Barcelona: Ed. Ariel, 1974) p. 36, afirma que, cuando se abrió la tumba de Tutankamón en 1922, el oro allí encontrado doblaba los depósitos del Banco Real de Egipto en la misma fecha.

2 Todas las citas del Antiguo Testamento están tomadas de Jose María Bover y Francisco Cantera Burgos (eds.), Sagrada Biblia. Versión crítica sobre los textos hebreo y griego (Madrid: Biblioteca de Autores Cristianos, La editorial Católica, 1961). 
Sin embargo, frente a las continuas alusiones, los hallazgos arqueológicos parecen desmentir ese amor y necesidad de acopio de joyas y piezas de orfebrería del pueblo hebreo. En palabras de Wright ${ }^{3}$ :

La primera impresión que tiene el arqueólogo ante las ruinas y manufacturas de Israel es que aquel pueblo era comparativamente pobre y falto de interés por el arte. Eso resulta especialmente cierto si se llega a Palestina después de haber estudiado las ruinas de Grecia, Egipto, Siria o Mesopotamia. Para el especialista en la Antigüedad griega o egipcia, Palestina es el más desolado y carente de interés de todos los países del mundo antiguo, ya que son muy pocos los objetos de mérito artístico o las ruinas arquitectónicas de proporciones impresionantes que han aparecido en los niveles anteriores a las épocas romana o árabe.

Pero esa impresión que nos da la arqueología es, si no falsa, al menos no totalmente fidedigna. No debemos olvidar que se trata de una ciencia auxiliar de la historia que trabaja con materiales selectivos; los que quedan ocultos y abandonados en asentamientos humanos. Tendemos a pensar que las joyas, por el valor intrínseco de sus materiales constitutivos, no se destruyen y muy bien podrían haberse conservado en mayor porcentaje hasta nuestros días, en yacimientos arqueológicos o en cualquier otro lugar. Pero, como los especialistas saben muy bien, el proceso es precisamente el contrario; si la más modesta pieza alfarera, una vez rota, pierde su valor y tirada en un basurero o abandonada en un antiguo asentamiento puede permanecer intacta durante siglos e incluso milenios, las joyas están sujetas a una casi eterna, reutilización o reciclado: Los objetos, sean de la clase que sean, compuestos de metales nobles y piedras preciosas se compran, se regalan, se ofrecen, se exhiben, se empeñan, se revenden, se intercambian, se prestan, se recuperan, se devuelven, se heredan, se estropean, se rompen, se arreglan, se restauran, se modernizan, se funden, se esconden, se roban, se pierden, se encuentran..., se reciclan una y otra vez de las maneras mas variadas; todo menos tirarlos o abandonarlos deliberadamente. Como veremos, el Antiguo Testamento nos ilustra ampliamente sobre la continua reutilización de las joyas y su escasa perdurabilidad, plasmada incluso en un proverbio: Proverbios 27, 24: "pues no es para siempre la riqueza, / ni la diadema de generación en generación".

No es casual que los mayores y mejores conjuntos conservados procedan de los llamados "tesoros", es decir, ocultamientos deliberados, que se realizaron en un momento de inestabilidad o guerra y cuyo propieta-

3 G. Ernest WRIGHT, Arqueología biblica (Madrid: Ediciones Cristiandad, 1975), p. 279. 
rio nunca pudo volver para recuperar las piezas, probablemente por su muerte. Los hallazgos en sepulturas son también notables aunque, curiosamente, en una proporción que aumenta según nos alejamos en el tiempo, característica ésta, no sólo documentable en la Tierra Prometida, sino también en otros lugares muy remotos y sin conexión. Y es que según avanza la historia y los metales nobles se convierten en un valor de cambio e intercambio, la tendencia a no abandonarlos, y a su nueva utilización aumenta (al cadáver se le pueden dejar algunas pequeñas joyas de uso cotidiano o especial significado, pero nunca se le enterrará con todos sus tesoros, por la mismas razones que a nadie se sepulta con los fajos de billetes que pudiera tener ahorrados; son valores demasiado importantes para los vivos). Además, la práctica de acompañar a los difuntos con sus joyas acarrea la no menos extendida de la profanación. En la lápida de un enterramiento israelita, cercano a Jerusalén y fechado aproximadamente en el 700 a $C$. aparece una inscripción que dice ${ }^{4}$ :

Este es [el sepulcro de ....] yahu que está sobre la casa.

No hay aquí ni oro ni plata, sino [sus huesos] y los huesos de sus esclava-esposa con él.

Maldito sea el hombre que lo abra

Pero ni la maldición, ni la declaración sobre la ausencia de joyas sirvieron para mucho y cuando se excavó la tumba, ya había sido saqueada. No olvidemos que para que los faraones pudieran enterrarse con sus magníficos tesoros fue necesaria la construcción de las monumentales pirámides e hipogeos que sólo en algunos casos han podido llegar intactos hasta nuestros días. Tampoco la rica orfebrería depositada en palacios o templos tiene asegurada su perdurabilidad y, además del riesgo de los hurtos individualizados, o el "desvío" hacia el patrimonio de sus guardianes, en épocas de cambios, revoluciones, inestabilidades políticas o guerras, estos objetos se convierten en el botín más preciado de los saqueadores. Para acercarnos a la verdadera dimensión de la joyería en cualquier época que no sea la contemporánea es necesario recurrir a los textos y a la iconografía ${ }^{5}$. Esto no quiere decir que en nuestro trabajo vayamos a despreciar los

4 G. Ernest WRIGHT, Arqueología bíblica (Madrid: Ediciones Cristiandad, 1975), pp. 250-251.

5 El estudio de Teresa Chapa y Juan PEREIRA, "El oro como elemento de prestigio social en época ibérica", Archivo Español de Arqueología, 64 (1991), pp. 23-35, aunque referido a la antigüedad hispana, muestra de manera clara y contundente la desproporción entre los escasos hallazgos arqueológicos y la rica y abundante joyería conocida por la estatuaria y las referencias escritas. 
datos y materiales que nos ofrece la arqueología; por el contrario, en todo momento intentaremos presentar toda la información que ilustre o contradiga el texto sagrado, pero él será la principal guía de nuestra exposición. Aunque, con frecuencia, en estos relatos el tema queda desbordado y alcanza proporciones míticas o legendarias que más tienen que ver con la mentalidad de un pueblo que con su joyería, lo que nos interesa obtener, más que detalladas descripciones de series de piezas, es la cosmovisión sobre los metales nobles y las piedras preciosas que el pueblo hebreo dejó plasmada en el Antiguo Testamento, sin duda una de sus facetas más representativas y perdurables.

\section{LOS ÍDOLOS}

Como ha sido ampliamente tratado ${ }^{6}$, el Antiguo Testamento no contiene la historia de un pueblo fiel a una religión monoteísta, sino que Yahveh, el único Dios oficialmente reconocido, mantendrá una larguísima y constante lucha contra las tendencias idolátricas que florecen en el pueblo escogido. Él mismo, en ocasiones, es denominado $\mathrm{El}$ o Baal -dioses cananeos- dentro de la tendencia al sincretismo religioso, tan extendida en el Mundo Antiguo, aunque algunos autores piensan que no se trata de una asimilación a estas divinidades sino de la aplicación del epíteto "Señor", que es lo que significan estas palabras al igual que Yahveh. Por otra parte, según David Noel Feedman ${ }^{7}$ hay indicios suficientes en el texto bỉblico iluminado por unas inscripciones halladas entre el sur de Negeb y la península de Sinaí, como para pensar que en tiempos preexílicos Asherah (nombre que se da a Astarté, en el Antiguo Testamento) era considerada popularmente como la consorte de Yahveh.

Pero al menos hay una faceta que individualiza y distingue al Dios hebreo del resto de las divinidades de la antigüedad que es la prohibición de reproducir su imagen, y aquí enlazamos de nuevo con el tema de la orfebrería ya que, como veremos a continuación, las imágenes de

\footnotetext{
6 William Foxwell AlBRIGHT, Yahweh and the gods of Canaán. A Historical Analysis of Two Contrasting Faiths (Indiana: Winona Lake, Eisenbrauns, 1990); Donal B. REDFORD, Egypt, Canaán, and Israel in Ancient Times (New Yersey: Princenton University Press, 1993); Jesús Luis Cunchillos, "Una lectura cananea de La Biblia", Visto desde Ugarit. El desciframiento de las escrituras cuneiformes y otros relatos (Madrid: Ediciones Clásicas, 1994), pp. 173-190.

7 David Noel FeEDMAN, "Yahweh of Samaria and His Asherah", Biblical Archaeologist. A publication of the American School of Oriental Research, vol. 50, núm. 4 (Diciembre, 1987), pp. 241-251.
} 
dioses, los llamados ídolos de la Biblia, tan populares entre la población son una de las principales producciones.

La prohibición de fabricarse ídolos es ampliamente tratada ${ }^{8}$, generando múltiples menciones reprobatorias que muestran la amplia difusión de la idolatría. Gracias a ellas conocemos bastante bien la tipología de estas representaciones:

Deuteronomio 4,16 no sea que os corrompáis y os fabriquéis escultura, figura de algún ídolo, representación masculina o femenina, 17 imagen de alguna bestia de la tierra, representación de cualquier ave alada que vuela por el cielo, 18 figura de algún ser que se arrastra por el suelo, imagen de cualquier pez que vive en las aguas debajo de la tierra; 19 y no sea que, alzando al cielo tus ojos y viendo el sol, la luna, las estrellas, todo el cortejo celeste, te dejes seducir y te prosternes ante ellos y les des culto [........] 23 Guardaros de olvidar la alianza que Yahveh, vuestro Dios, pactó con vosotros y de fabricaros escultura, representación de cuanto Yahveh, vuestro Dios, te ha prohibido;

Además de este tipo de menciones genéricas, varios episodios directamente relacionados con los ídolos, amplían nuestro conocimiento sobre el tema. En primer lugar, trataremos de los terafim, dioses domésticos, vinculados y depositados en las diversas casas patriarcales que muestran que el culto a los ancestros, característico de los cananeos estaba ampliamente difundido entre los judíos ${ }^{9}$. Cuando Raquel, esposa de Jacob e hija de Labán, abandona la casa paterna, siguiendo a su marido y familia roba a su padre los terafim (Génesis 31,19) cuya posesión, según la legislación horrita de mediados del segundo milenio a. C., conocida por los documentos hallados en las excavaciones de Kir-Kud y Nuzi, al E. del Tigris, le daba derecho a participar en la herencia paterna. Esto explica el disgusto de Labán al comprobar su desaparición, a la que da más importancia que la pérdida de sus hijas y nietos, marchando tras Jacob para recuperarlos. Estos dioses domésticos de los que no se ha identificado ningún ejemplar en nuestra zona de estudio, aunque probablemente serían muy similares a los recuperados en Nuzi, no debían ser de gran tamaño, pues Raquel se sienta encima de ellos para que su padre no los descubra al registrar el campamento (Génesis 31,34). Finalmente Jacob obliga a Raquel y el resto de su familia a desprenderse de todos los ídolos o amuletos

8 Así ha quedado expresamente mencionado en Éxodo 20,23 y 34,17; Levítico 19,4; Deuteronomio 4,16-23; 5,8-9; 7,25; 12,13.

9 J. L. Cunchillos en "Literatura religiosa de Ugarit", op. cit., p. 147, señala que los ancestros estaban elevados a la categoría de dioses, hijos de Ilu (El, en la Biblia), formando parte de ellos los reyes. Son dioses de carácter benéfico ligados a la fertilidad de la tierra y la fecundidad de las familias. 
que indicaran un culto diferente al de Yahveh: Génesis 35, 2 "Dijo, pues Jacob a su familia y a todos lo que con él estaban: "Retirad los dioses del extranjero que hay en medio de vosotros [...] 4 Entregaron, en efecto, a Jacob todos los dioses extranjeros que tenían en su poder y los pendientes de sus orejas, y Jacob los escondió al pie de la encina que había junto a Sikem".

Aquí tenemos la formación de uno de esos "tesoros" aludidos en la introducción y un posible destino para las joyas que muestran las desviaciones idolátricas de sus poseedores, entre las cuales, como veremos más abajo, se encuentran los pendientes. Mayor tamaño debía tener el terafim con que Mikal, esposa de David e hija del rey Saúl, suplantó a su marido, para evitar que su padre le prendiera y diera muerte como planeaba: 1 Samuel 19, 13 "Entonces cogió Mikal el terafim y lo colocó sobre el lecho y, poniendo a su cabecera un paño de pelo de cabra, lo cubrió con el cobertor."

Una última cita nos amplía la información sobre el tipo de culto que recibían:

Jueces 17, 3 Devolvió él los mil cien siclos de plata a su madre, y su madre dijo: "Consagro solemnemente por mi mano esta plata a Yahveh en favor de mi hijo para hacer un ídolo y una estatua fundida" [...] 4 [...] tomó ésta doscientos siclos de plata y los entregó al fundidor, quien hizo de ellos un ídolo y estatua fundida, que quedó en casa de Mikayehu. 5 De esta suerte tuvo un santuario el tal Miká, y fabricó un efod y terafim [...] 7 Hubo, asimismo, un joven de Belén de Judá, de la familia de Judá, el cual era levita y moraba allí como forastero [...]

10 Miká le contestó:

-Quédate conmigo y me servirás de padre y sacerdote; en cambio, te daré yo diez siclos de plata por año, un juego de vestidos y tu sustento.

Jueces 18, 17 Los cinco que habían ido a explorar el país subieron y entraron allá, apoderándose del ídolo, el efod, los terafim y la imagen fundida, en tanto que el sacerdote estaba ante la puerta de entrada con seiscientos hombres ceñidos con las armas de guerra,

18 [...] y díjoles el sacerdote:

- ¿Qué estáis haciendo?

19 Contestáronle:

- Calla; pon la mano en tu boca y ven con nosotros, y nos servirás de padre y sacerdote. ¿Es mejor para ti ser sacerdote de la casa de un hombre o serlo de una tribu o una familia de Israel?

El texto distingue cuatro clases de objetos religiosos: el ídolo, la imagen fundida, el efod (del que trataremos al hablar de la indumentaria sacerdotal) y el terafim, o los terafim, quedando claro que los dos primeros son de plata, obra de fundidor, mientras que del terafim no se menciona su materia, que podría ser de algún tipo de piedra preciosa o 
semipreciosa o de madera recubierta de láminas de oro o plata, a modo de imagen vestidera. Merece la pena destacar que en los tres relatos sobre terafim alguna mujer de la familia o la casa interviene, bien robándolos, empleándolos para suplantar a una persona, o dando la plata necesaria para su fabricación. El protagonismo femenino tanto en las prácticas mágicas y religiosas como en el empleo de joyas será una constante que perdurará a través de los tiempos.

Más información poseemos sobre las representaciones de otras divinidades, entre las cuales sin duda la más conocida es el célebre becerro de oro:

Éxodo, 32, 1 Mas viendo el pueblo que Moisés tardaba en bajar de la montaña, se congregó en torno a Aarón y dijéronle:

-Ea, haznos un dios que vaya delante de nosotros; pues ese Moisés, ese hombre que nos ha sacado de Egipto, no sabemos qué ha sido de él.

2 Respondióles Aarón:

-Arrancad los zarcillos de oro que llevan en las orejas vuestras mujeres, vuestros hijos y vuestras hijas y traédmelos.

3 Arrancóse, en efecto, todo el pueblo los zarcillos de oro que llevaba en sus orejas y trajéronlos a Aarón. 4 Él lo recibió de sus manos, le dio forma con el buril y transformólo en un becerro de fundición.

El conocimiento de las religiones del Próximo Oriente, incluida la de los cananeos, que nos han proporcionado el desciframiento de las escrituras y la arqueología, ha llevado a los especialistas a pensar que el becerro de oro no era en realidad la representación de una divinidad, sino el soporte visible de una deidad invisible, probablemente Hadad, el dios de las tormentas y la fertilidad, en tiempos identificado con Baal, a quien con frecuencia se representaba de pie sobre un becerro o toro, o con la sola imagen del animal al que se asocia. La posibilidad, indicada por Francisco Cantera, de que fuera el propio Yahveh el Dios invisible que soportara el becerro parece quedar totalmente descartada por la adversa reacción de Moisés al descubrirlo. No se trata del único ejemplar mencionado en el Antiguo Testamento, también adquieren cierto renombre el par de becerros de oro, claramente asociados al culto a Baal, de la ciudad de Bet-aven, en el reino de Samaria (Isaias 10,10; Oseas 8,4-6; 10,5-6; 13,2 y 2 Reyes 17, 16), donde, al parecer tuvieron especial florecimiento las prácticas idolátricas. Son contadas las representaciones de toros o becerros que nos ha proporcionado la arqueología. Albright ${ }^{10}$ menciona que su imagen, con o sin dios encima es conocida en Palestina por los sellos,

10 William Foxwell ALBRIGHT, Yabweb and the gods of Canaan. A Historical Analysis of Two Contrasting Faiths (Indiana: Winona Lake, Eisenbrauns, 1990), p. 198. 
además de la existencia de la estatua de un toro levantado procedente de Hazor y fechado en el tercer cuarto de la tercera centuria a. C., aunque no da otros detalles ${ }^{11}$. Un paralelo más interesante está depositado en el Museo de Israel ${ }^{12}$; se trata de la estatua de un becerro de bronce, encontrado en la región de Samaria y fechado a principios de la doceava centuria.

En la introducción comentábamos la casi eterna reutilización de los metales nobles y las piedras preciosas y el último texto reproducido nos da un buen ejemplo de ello. Pero el oro empleado en la fabricación de ídolos, es el único que luego no podrá ser utilizado para otros fines. Para que esto fuera así, Jacob tuvo que esconder los terafim que robara Raquel, aunque mucho más sofisticado fue el método ingeniado por Moisés ${ }^{13}$ : Éxodo 32, 20 "Luego tomó el becerro que habían hecho, quemólo en el fuego y lo molió hasta dejarlo hecho polvo, esparciéndolo después en el agua, que hizo beber a los hijos de Israel".

Más adelante, las Crónicas nos refieren un caso semejante: 2 Crónicas 34, 3 [...] "empezó a limpiar Judá y Jerusalén de los lugares altos, las aserás ${ }^{14}$, las imágenes esculpidas y las imágenes de fundición. 4 [...] y las redujo a polvo, que esparció sobre las sepulturas de quienes les habían ofrecido sacrificios".

La posesión, fabricación o adoración de "ídolos de madera, dorados y plateados, obra de artífices que ni sienten, ni oyen", según las expresiones más comunes ${ }^{15}$, incluso mereció capítulos enteros de algunos libros en los que, ampliando el tema, se tratan de ridiculizar y desprestigiar. Son especialmente ilustrativos el número 44 de Isaías, "Diatriba contra la idolatría" y el 6 de Baruk, "Epístola de Jeremías contra los ídolos". Aunque la cita resultará un poco amplia, creo que los datos que ofrece sobre la fabricación, tipo de culto y otros aspectos directamente relacionados con la joyería merecen la casi completa reproducción de la última:

Baruk 6, 1 Por los pecados que pecasteis delante de Dios seréis llevados a Babilonia cautivos por Nabucodonosor, rey de los babilonios [...] 3 Ahora, pues,

11 Ibidem, p. 195

12 Bradford D. KELLEHER (publisher), Treasures of the Holy Land. Ancient art from the Israel Museum (New York: The Metropolitan Museum of Art, 1986), p. 153.

13 En el Deuteronomio 9,21, también se nos relata este episodio.

${ }^{14}$ Las aserás es la expresión mas común para referirse a las representaciones de Astarté, llamada Asherah o Aserá en el Antiguo Testamento. El frecuente empleo del plural nos indica que normalmente se tenían varias.

15 Expresiones semejantes aparecen en Salmos 134,15-18: Sabiduria 13,10; Isaías 46,6-7; Jeremias 10,3-15; Oseas 13,12, etc. 
veréis en Babilonia dioses de plata, de oro y de madera llevados sobre hombros, infundiendo miedo a los gentiles. 4 Guardaos, pues, no sea que también vosotros os hagáis del todo semejantes a los extranjeros y os coja miedo de ellos 5 al ver turbas delante y detrás de ellos adorándolos [....]

7 Porque la lengua de esos dioses ha sido limada por el artífice, y ellos están dorados y plateados, pero son pura farsa y no pueden hablar. 8 Y como se hace con una doncella amiga de galas, tomando oro, labran coronas para las cabezas de esos dioses. $9 \mathrm{Y}$ acaece que los sacerdotes, sustrayendo a esos dioses oro y plata, lo gastan en su propio provecho, y aun dan parte de ello a las rameras de los burdeles. $10 \mathrm{Y}$ los aderezan como a los hombres con ropajes a esos dioses de plata, de oro y de madera; mas ellos no se libran del orín y de los gusanos. 11 Vestidos como están de púrpura, límpianles la cara sucia del polvo de la casa, que se acumula sobre ellos. 12 Y lleva cetro como un hombre juez del distrito, que no matará al que peca contra él. 13 Lleva también daga o hacha en su diestra, mas no se defenderá a si mismo de la guerra o de los ladrones [...]

15 pues como un vaso de un hombre, si se quiebra, se hace inútil, así son sus dioses. Colocados en las casas, 16 sus ojos están llenos del polvo levantado por los pies de los que entran. 17 [...] así las casas de los dioses asegúranlas los sacerdotes con puertas, cerrojos y trancas para que no sean saqueadas por los ladrones. 18 Enciéndenles lámparas, mas aún que para sí mismos, de las cuales ninguna pueden ver. 19 Son como vigas de una casa, y dicen que sus corazones son carcomidos. A los bichos de la tierra que los devoran, a ellos y a sus vestidos, no los sienten. 20 Tienen ennegrecido su rostro por el humo de la casa. 21 Sobre su cuerpo y sobre su cabeza revolotean lechuzas, golondrinas y otros pájaros y asimismo [se lanzan] los gatos. 22 Por donde conoceréis que no son dioses. No los temáis pues.

23 Porque el oro de que están revestidos para embellecerlos, si no limpian el orín, no harán que brille. Pues ni cuando eran fundidos lo sentían. 24 A sumo precio han sido comprados esos trastos en que no hay espíritu. 25 Sin uso de pies son llevados a hombros, exhibiendo a los hombres su propia ignominia, y se avergüenzan aun los que los sirven, porque de caer en tierra, no pueden levantarse. $26 \mathrm{Ni}$, si uno lo planta de pie, se moverá por sí mismo; ni, si lo inclina, se enderezará; mas como a cadáveres les son presentadas las ofrendas. 27 Sus víctimas véndenlas los sacerdotes para sacar provecho; asimismo, también sus mujeres hacen de ellas salazón, y ni al pobre ni al desvalido dan parte. Sus víctimas tócanlas la parida y la menstruante. 28 Entendido, pues, por aquí que no son dioses, no los temáis.

29 Porque ¿de dónde podrían llamarse dioses? Pues mujeres presentan ofrendas a unos dioses de plata, de oro y de madera. $30 \mathrm{Y}$ en las casas de ellos siéntanse los sacerdotes con las túnicas desgarradas y con las cabezas y las barbas raídas, teniendo las cabezas descubiertas. $31 \mathrm{Y}$ cuando vocean delante de sus dioses, rugen, como si se hallasen en un banquete funerario. 32 De la vestimenta de los dioses, los sacerdotes, con lo que hurtan, visten a sus mujeres y a sus hijos. $33 \mathrm{Ni}$ cuando de alguien reciben algún mal, ni cuando algún bien, podrán dar el pago correspondiente. Ni poner rey pueden ni quitarlo. 34 Asimismo, ni riquezas ni un ochavo son capaces de dar [...] $37 \mathrm{Ni}$ de la viuda se compadecerán ni al huérfano favorecerán. 38 A los peñascos del monte son semejantes esos trastos de madera, o dorados, o plateados; y los que les sirven se verán corridos. 39 ¿Cómo, pues, habrá que pensar o decir que son dioses? 
40 Tanto más cuando los mismos caldeos los desacreditan; los cuales, cuando ven un mudo que no puede hablar, presentándole una imagen de Bel, le piden que le haga hablar. Como si él pudiera sentir. $41 \mathrm{Y}$ no pueden, recapacitando, abandonarlos, pues no tienen sensatez. $42 \mathrm{Y}$ las mujeres ceñidas de cuerdas de junco, estánse sentadas en los caminos quemando el salvado; 43 y cuando alguna de ellas, arrastrada por alguno de los transeúntes, duerme con él, escarnece a la vecina, por que ni fue digna como ella ni se rompió su cuerda. [...]

45 Por artesanos y orfebres han sido labrados: no serán otra cosa que lo que quieran los artífices que sean. $46 \mathrm{Y}$ los mismos que los labran no se harán longevos: ¿Cómo habrán de ser dioses los objetos labrados por ellos? 47 Pues dejaron supercherías y oprobio a los venideros. 48 Pues cuando les sobreviene guerra o calamidades deliberan entre sí los sacerdotes dónde se ocultarán con ellos. 49 ¿Cómo pues no se debe pensar que no son dioses los que ni de la guerra ni de las calamidades se salvan. [...]

51 ¿En qué, se da a conocer que no son dioses?

52 Rey de una región no establecerán, ni lluvia a los hombres darán. 53 No sentenciarán en sus pleitos ni librarán al que padece agravio, impotentes como son; pues son como cornejas entre el cielo y la tierra. 54 Pues cuando se prenda fuego en la casa de esos dioses de madera, dorados o plateados, sus sacerdotes escaparán y se pondrán a salvo, más ellos como postes se abrasarán en medio de las llamas. A un rey y a un ejercito enemigo no resistirán. [...]

$57 \mathrm{Ni}$ de ladrones ni de salteadores se salvarán unos dioses de madera, y plateados, y dorados, cuyo oro, plata y vestimenta que los envuelve les quitan los valientes, y se irán con ello sin que ellos puedan socorrerse a sí mismos [...] 63 Por donde no se ha de pensar ni decir que sean dioses, impotentes como son para hacer justicia y para hacer bien a los hombres. [...]

66 [...] ni brillarán como el sol, ni iluminarán como la luna. 67 Superiores a ellos son las fieras, que, refugiándose bajo cubierto, pueden proporcionarse provecho a sí mismas. [...]

69 Pues como en un cohombral un espantajo nada guarda, así son sus dioses de madera [...]

71 Por la púrpura y su brillante aderezo, que sobre ellos se pudre, conoceréis que no son dioses. Ellos mismos, al cabo serán carcomidos y serán una horrura en el país. 72 Mejor pues, un hombre justo que no tiene ídolos porque estará lejos de merecer reproche.

La ridiculización del culto a las impotentes imágenes, sujetas a las más degradatorias contingencias e incapaces de procurar algún bien al hombre es feroz ${ }^{16}$, pero, además, el texto, contiene importantes informaciones sobre los ídolos como sus materiales, de madera chapada en oro (aunque también en el versículo 23 se menciona la fundición), el ser imágenes

16 Su comparación con las imágenes producidas por el cristianismo, obligaron a Cantera a añadir la siguiente nota a pie: "La sátira del profeta contra los ídolos no es aplicable al culto de las sagradas imágenes, que jamás los cristianos han considerado como dioses, sino como simple representación, o de Dios, a quien únicamente se adora, o de los santos, a quienes se venera". 
vestideras, (versículos, 10, 19 y 32), los tipos de indumentaria y complementos que portaban, como el cetro y la daga (12 y 13), el robo o desvío de sus bienes por los sacerdotes (9, 26 y 32), su saqueo por ladrones o como botín de guerra $(13,17$ y 57). También se dan detalles sobre el culto como el ser portados en procesión (3 y 25), la presentación de ofrendas de animales (26), la prostitución divina a la que al menos una vez en su vida debían someterse las seguidoras de Asherah (42) que las obligaba a llevar un cinturón de cuerdas de junco como distintivo hasta que cumplie-
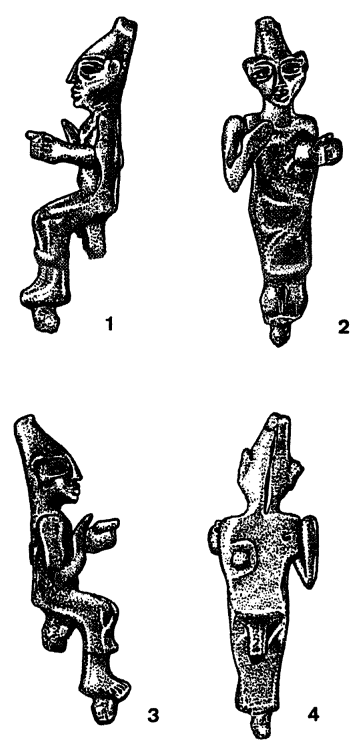

\begin{tabular}{llllll}
0 & 1 & 2 & 3 & 4 & 5 \\
\hline
\end{tabular}

FIG. 1.-Figurita del dios El procedente de Kinneret. Tomada de Volkmar FRITZ, An Introduction to Biblical Archaeology (England: Sheffield, JSOT Press, 1994), p. 146. ran con el precepto, su estado de abandono y suciedad colocados en casas y templos, etc. Como tantas veces vaticinaron los profetas bíblicos ${ }^{17}$, las esculturas de ídolos, debieron ser robadas quemadas, saqueadas o destruidas por unos $\mathrm{u}$ otros procedimientos, pues son muy escasos los ejemplares de cierto tamaño que han llegado hasta nuestros días ${ }^{18}$.

Por lo bien que se ajusta a las descripciones del Antiguo Testamento ${ }^{19}$ (Isaías 40, 19: "El artífice funde el ídolo / y el orfebre lo recubre de oro batido y cadenas de plata le suelda. / 20 Escoge un trozo de madera que no se pudra, / búscase un hábil artista / para erigir un ídolo que no se tambaleen) destaca la figurilla de un dios sedente (posiblemente $\mathrm{El}$, cabeza del panteón cananeo), realizada en bronce y chapada en oro, que apareció en Meguido, perteneciente al periodo cananeo, Edad del Bronce y fechada en el siglo XIII a. C. Casi idéntica en todos sus detalles es otra representación del mismo dios procedente de Kinneret ${ }^{20}$, aunque ésta pertenece ya a la Edad del Hierro (ver fig. 1). Más numerosas son las pequeñas estatuillas de Baal (hijo de El) dios de las tormentas, la vegetación y la fertilidad, al

17 Deuteronomio 12,3; Isaías 2,20; 10,10-11; 31,7; Daniel 11,8; Oseas 8,4-6 y 10,5-6.

18 En el libro de Daniel se nos dan las dimensiones de uno de estos ídolos: Daniel 3,1 «El rey Nabucodonosor fabricó una estatua de oro cuya altura era de sesenta codos, y su anchura de seis. Erigióla en la llanura de Dura, en la provincia de Babilonia".

19 Encontramos también detalles sobre la fabricación de los ídolos en Jeremías 10,3-15 e Isaías 44.

20 Volkmar FRITZ, An Introduction to Biblical Archaeology (England: Sheffield, JSOT Press, 1994), p. 146. 
que se invocaba con mucha frecuencia por considerarse más próximo a los intereses humanos. Se le suele representar de pie con faldellín y tiara, blandiendo un rayo en una de su manos (está bastante difundida una estatuilla suya de bronce procedente de Ras Shamra). De las diosas, especialmente Astarté o Asherah, esposa de El y diosa de la fertilidad, (aunque a veces también se la menciona como consorte de Baal), más que estatuas, se conservan representaciones en placas de arcilla o metálicas y en grabados o repujados de colgantes y sellos, de los que hablaremos más abajo por considerarlos amuletos más que ídolos, aunque sin duda estos también existieron, estando identificada con Astarté una figura de plata perteneciente a la Edad del Bronce y recuperada en Nahariya ${ }^{21}$. En el texto sagrado se encuentran múltiples alusiones a esta diosa a la que normalmente se denomina aserás, en plural y con minúsculas ${ }^{22}$. Con frecuencia, se representaba o simbolizaba por medio de árboles, lo que explica las expresiones: "demoleréis las aserás o talareis las aserás".

Grandes o pequeños han desaparecido los renombrados "ídolos de fundición" de oro o plata y los de madera chapada en estos materiales, complementados con ricas indumentarias y aderezos de cuya proliferación sólo nos han quedado los testimonio bíblicos.

\section{AlgunOS EJEMPLOS DE MAGIA Y ADIVINACióN}

Es evidente que la joyería tenía un doble propósito en estas culturas: además del deseo de ornamentarse, el poder mágico de los amuletos como protectores y ahuyentadores de los males es también significativo ${ }^{23}$.

Las prácticas mágicas, supersticiosas y adivinatorias como métodos para controlar los acontecimientos personales o sociales que sobrepasan el desarrollo científico en un lugar y una época determinadas, han florecido en todas las culturas, y el Antiguo Testamento nos ofrece múltiples ejemplos de ello, aunque aquí sólo las trataremos cuando se relacionan con las producciones joyeras. Como veremos, el propio Yahveh, sus emisarios (los ángeles) y sus más fieles seguidores recurren a la magia en más de una ocasión, mostrando sólo su repulsa hacia los amuletos que representan o invocan el poder de otras divinidades. Así, José, después de haber sido

\footnotetext{
21 Archaeological Enciclopedia of the Holy Land, Avraham NEGEV ed. (Jerusalem: Weidenfel \& Nicolson), 1972, p. 40.

22 En 2 Reyes 21,7 se relata que Manasés colocó una imagen de Aserá en el templo de Jerusalén. También en el mismo libro $(17,16)$ se menciona cómo en el reinado de Oseas se fabricaron aserás.

23 Avraham NEGEV, op. cit., p. 172 (traducción personal).
} 
vendido por sus hermanos a los egipcios, se vale de sus dotes adivinatorias para interpretar los sueños del faraón y ocupar un puesto de poder. Posteriormente, cuando los hermanos acuden a Egipto para comprar grano, los despide colocando en el borde de sus costales, el dinero que habían pagado, añadiendo en el de Benjamín su copa de plata:

Génesis 44, 4 Cuando ya habían salido de la ciudad y no estaban aún lejos, José dijo a su mayordomo:

-Ea, corre tras de esos hombres y cuando les hayas dado alcance, diles: “CCómo habéis vuelto mal por bien? ¿y por qué me habéis robado la copa de plata? ¡Es la misma en la que bebe mi amo y con la que él hace sus augurios!

El texto parece indicar con claridad que la lecanomancia o arte de adivinar por el ruido de las piedras preciosas en una copa o por el movimiento del agua en ella era conocida entre los judíos y egipcios. De mayor antigüedad (2200-2000 a. C.), la copa de plata depositada en una tumba cananea de Ein-Samiya, también debió tener algún tipo de función mágico-religiosa. Se trata de una importación mesopotámica, como nos señala su decoración realizada con incisiones y repujado, compuesta por elementos muy frecuentes en la antigua imaginería mesopotámica (la serpiente, la planta, el individuo con torso y cabeza humana y el resto del cuerpo de toro, el creciente lunar, el sol y las rosetas) aunque se desconoce con exactitud qué mito o leyenda representa ${ }^{24}$ (ver fig. 2).

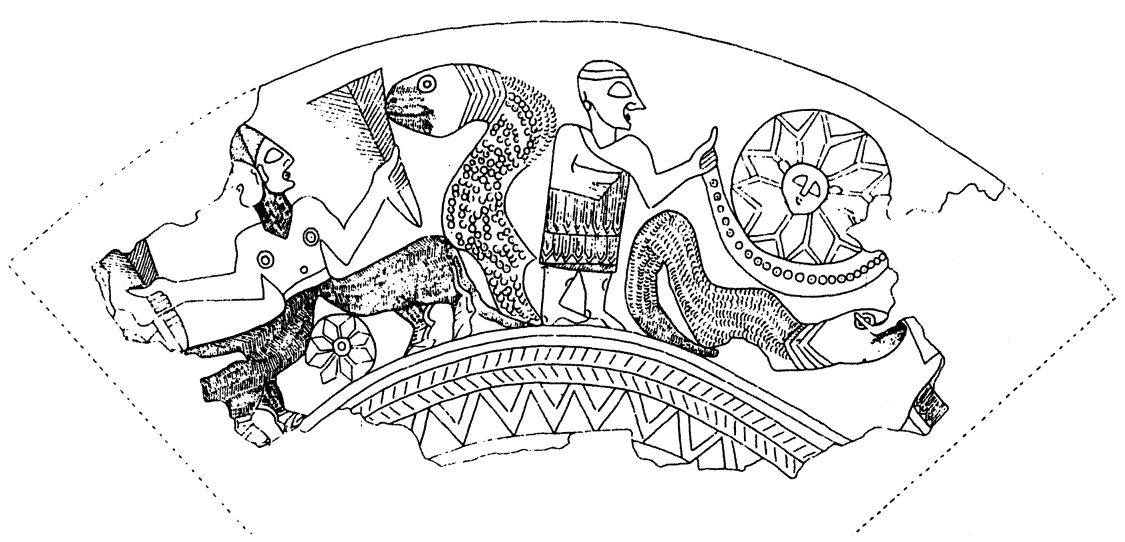

FIG. 2.-Decoración de la copa de plata de Ein Samiya. Dibujo del Museo de Israel.

24 Bradford D. KELleHER (publisher), Treasures of the Holy Land. Ancient art from the Israel Museum (New York: The Metropolitan Museum of Art, 1986), pp. 100-102 y Suzanne RICHARD, "The Early Bronce Age: The rise and collapse of urbanism", Biblical Archaeologist, vol. 50, núm. 1 (Marzo 1987), pp. 22-44. 
Asimismo, por indicación de Dios, Moisés puso en práctica una fórmula de magia simpática para proteger al pueblo escogido de las picaduras de serpiente durante su dura estancia en el desierto:

Números $21,4[\ldots]$ pero en el camino se desalentó el pueblo, 5 y habló contra Dios y contra Moisés: "iंPor qué nos habéis hecho subir de Egipto para morir en el desierto, pues no hay ni pan ni agua, y nuestra alma siente hastío de este alimento miserable?" 6 Yahveh envió entonces contra el pueblo serpientes abrasadoras, que mordieron al pueblo, muriendo mucha gente de Israel. $7 \mathrm{El}$ pueblo acudió a Moisés, exclamando: «Hemos pecado por haber hablado contra Yahveh y contra ti; ruega a Yahveh que aparte de nosotros las serpientes!n Moisés suplicó en efecto, por el pueblo, 8 y Yahveh dijo a Moisés: "Hazte una serpiente abrasadora y colócala sobre una pértiga, y acaecerá que todo el que haya sido mordido y la mire vivirán. 9 Moisés fabricó, efectivamente, una serpiente de bronce y púsola sobre la pértiga; ahora bien, cuando una serpiente mordía a un hombre, si éste miraba a la serpiente de bronce conservaba la vida.

La serpiente de bronce se conservó con el resto del ajuar dedicado a Dios, siendo depositada en el templo de Salomón, pero con este símbolo de fertilidad e inmortalidad en múltiples culturas y atributo de varias deidades de la antigüedad, se produjo el fácil tránsito de la magia a la idolatría y finalmente sus mismos poderes, aconsejaron la destrucción:

2 Reyes 18, 1 [...] subió al trono Ezequías [...] 3 Hizo lo recto a los ojos de Yahveh [...] 4 Suprimió el culto de las alturas, quebró las massebás, taló las aserás y machacó la serpiente de bronce que había fabricado Moisés; porque hasta aquel tiempo los israelitas le habían quemado incienso denominándola Nejustán.

Conviene indicar que el bronce alcanzaba una altísima consideración en la sociedad israelita de los períodos cananeo e israelita (Edades del Bronce y Hierro) y era frecuentemente empleado en la orfebrería y joyería, mereciendo la clasificación de metal noble como muestran las numerosas piezas encontradas de este material, desde pulseras, hasta grandes piscinas para libaciones ("el mar de bronce"), y los propios textos nos indican: Esdras 8, 25 "y peséles la plata, el oro y los utensilios, ofrenda para la casa de nuestro Dios [...] 27 [...] y dos vasos de hermoso bronce de brillo áureo, tan preciosos como el oro."

Por otra parte, no es el único ejemplo de magia simpática que implica la fabricación de alguna joya por indicación, o con consentimiento divino. En el que ofrecemos a continuación, se muestra además el conocimiento de que la peste era transmitida por ratas:

1 Samuel 5,1. Cogieron, pues, los filisteos el arca de Dios y la condujeron desde Ebenha-Ezer a Asdod. 2 [...] y la metieron en el templo de Dagón, colocándola junto a éste. [...] 
6 Luego la mano de Dios cargó pesadamente sobre los asdodeos, y los llenó de espanto, hiriéndolos con tumores, tanto a Asdod como a su comarca.

[...] 8 [...] - Llévese el arca del Dios de Israel a Gat [...]

9 Mas en cuanto la trasladaron, la mano de Yahveh originó en la ciudad enorme perturbación e hirió a los ciudadanos todos, chicos y grandes, de suerte que les salieron tumores. 10 Entonces enviaron el arca de Dios a Eqrón; [...] 11 [...] sobrevino mortal perturbación en toda la ciudad, descargando allí durísimamente la mano de Dios. 12 Aun las personas que no morían eran llagadas de tumores, subiendo los alaridos de la ciudad hasta el cielo,

6, 2 Entonces convocaron los filisteos a los sacerdotes y los adivinos, diciendo: — ¿Qué hacemos con el arca de Yahveh? Declaradnos cómo la hemos de enviar a su lugar.

3 [...] - Si mandáis el arca del Dios de Israel, no la remitáis de vacío, mas ofrecedle una expiación.

4 [...] ¿Cuál es la ofrenda expiatoria que hemos de ofrecerle?

A lo que replicaron:

-Según el numero de los principados filisteos, cinco tumores de oro y cinco ratones de oro, por cuanto sufrís una misma plaga todos vosotros y vuestros príncipes. Haréis, pues, unas figuras de vuestros tumores y otras de los ratones que destruyen el país, y daréis gloria al Dios de Israel. Quizá aligere el peso de su mano de sobre vosotros y de sobre vuestros dioses y vuestra tierra [...] 8 Luego tomad el arca de Yahveh y colocadla en el carro, poniendo junto a ella, en un cofrecito, los objetos de oro que le remitís en expiación, y dejadla libre que se vaya $[. .$.

17 Los tumores de oro que los filisteos ofrecieron como expiación a Yahveh son éstos: por Asdod, uno; por Gaza, uno; por Asqalón, uno; por Gat, uno por Eqrón, uno. $18 \mathrm{Y}$ los ratones de oro fueron como el número de todas las ciudades filisteas de los cinco principados, tanto ciudades fortificadas como no muradas.

Las joyas que representan animales de significado mágico-simbólico son relativamente abundantes, en especial las serpientes como remate de brazaletes, aunque conviene precisar que este reptil suele simbolizar la eterna juventud y la fertilidad, más que el uso arriba referido. También hay que mencionar los abundantísimos escarabeos, de los que trataremos al hablar de la joyería masculina. Además, formando parte de un tesoro excavado en Tell El-Ajjul ${ }^{25}$, se hallaron importantes joyas, entre ellas un conjunto de cuatro pequeñas moscas y una larva realizadas con gruesas láminas de oro. Aunque no se duda de su origen cananeo son perfectamente comparables a los amuletos egipcios con forma de mosca que frecuentemente se distri-

25 En este yacimiento de mediados del segundo milenio, al que nos volveremos a referir en más de una ocasión, se ha encontrado el más importante conjunto de joyería de la antigüedad israelita, tanto en las tumbas, como en numerosos tesoros domésticos en los que se mezclaban joyas rotas, con otras sanas y restos de despojos de oro y plata. Estos hallazgos hacen pensar que en la localidad se situaba un centro de manufactura de joyas, con un gremio de orfebres instalados. 
buían entre los soldados por actos de excepcional valor, aunque desconocemos cuál es exactamente la propiedad o cualidad que se les atribuía ${ }^{26}$. Todas ellas se rematan por la cabeza en un pequeño aro de suspensión que indica su empleo como colgantes. Otros animales representados en joyas son las cabras, que debía ser el tipo de ganado mayoritario y por tanto con un alto significado económico y susceptible de constituirse en objeto de prácticas mágicas. Su empleo como amuleto está bien representado en el Imperio Sirio dentro de la Tumba del Señor de las Cabras ${ }^{27}$ (yacimiento de Ebla, Bronce medio II, alrededor del 1700 a.C.), donde la parte superior del cuerpo de una cabra de bronce constituía el remate de los brazos de un trono y además han aparecido cuatro cabras de marfil, en miniatura, que formaban parte de un amuleto.

Si en la actualidad la plata es el metal al que se atribuyen propiedades mágicas y por ello suelen ser de esta materia muchos amuletos, tantos los textos como la arqueología indican claramente que en tiempos del Antiguo Testamento estas propiedades estaban mejor contenidas en el oro. Mas abajo veremos que las prácticas mágicas, sobre todo el uso de amuletos son preferentemente femeninos, aunque no de forma exclusiva; También los varones y los animales domésticos cuando se ven amenazados buscan este tipo de protección y sin duda, las continuas guerras y enfrentamientos eran las ocasiones en que se hacían más necesarios:

II Macabeos 12, 39 Al día siguiente, como la necesidad lo requería, vinieron los de Judas para levantar los cadáveres de los caídos y con sus parientes depositarlos en los sepulcros de sus padres. 40 Entonces, bajo las túnicas de cada uno de los caídos, encontraron objetos sagrados de los dedicados a los ídolos de Yamnia, que la ley prohibía a los judíos. Fue entonces evidente a todos que por esta causa habían sucumbido.

Jueces 8, 21 [...] Levantóse, pues, Gedeón y mató a Zébaj y Salmunná, y cogió las medias lunas que sus camellos llevaban al cuello.

La colocación de amuletos a los animales domésticos, especialmente a los de gran valor económico, cuando se les conduce a una contienda, todavía hoy es documentable en los países del ámbito mediterráneo. Por otra parte, no nos cabe duda sobre el carácter mágico de las medias lunas, de las que más abajo se aclara que iban en collares, siendo una de las formas más extendida en la joyería mediterránea. En el periodo que estudiamos, probablemente se trataban de un símbolo de Astarté, la diosa

\footnotetext{
26 Bradford D. Kelleher, op. cit., pp. 123-124.

27 Paolo MATTHIAE, "New discoveries et Ebla: The excavation of the Western palace and the royal necropolis of the Amorite Period", Biblical Archaeologist, vol. 47, núm. 1 (Marzo 1984).
} 
de la fertilidad y la vida, tanto humana como animal y vegetal, a la que con cierta frecuencia, se representa como "Señora de las fieras", flanqueada por ciervos u otros animales agrestes, o de pie encima de un caballo.

SÍMBOLOS Y FUNCIONES DE LA JOYERÍA FEMENINA

Isaías 3, $16 \mathrm{Y}$ Yahveh ha dicho: / Por cuanto son altaneras las hijas de Sión, y caminan con el cuello estirado / y miradas provocativas,

andan a pasitos menudos / y hacen tintinear las ajorcas de sus pies,

17 el Señor cubrirá de tiña / la coronilla de las hijas de Sión / y Yahveh descubrirá sus vergüenzas.

18 Aquel día arrancará el Señor el ornato de las ajorcas de los pies, las diademas y las lunetas, 19 los pendientes y las pulseras y los mantos, 20 las cofias y las cadenillas [para dar los pasos cortos], las fajas, los frascos de perfumes y los amuletos, 21 las sortijas, los anillos de la nariz, 22 los vestidos preciosos, las manteletas, los chales ${ }^{28}$ y las bolsas, 23 los espejos, las camisas de lino, los turbantes y los mantones, 24 y sucederá que en lugar de bálsamo habrá putrefacción; / y en lugar de cinturón, una cuerda; y en lugar de trenza, calva; /y en lugar de lujoso vestido, ceñidor de saco, quemadura en lugar de belleza.

Muchas veces se ha citado la apocalíptica visión que el profeta Isaías tuvo sobre la indumentaria de las mujeres de Sión, la más amplia enumeración de aderezos femeninos contenida en el texto sagrado, que también aquí nos servirá de guía. La primera impresión tras su lectura es que las mujeres se ataviaban con el lujo y profusión característico de las antiguas culturas orientales. También marca la pauta del tipo de referencias sobre la joyería, que, aunque abundantes, nos proporcionan escasa información sobre cada pieza en concreto, si exceptuamos su nombre y eventualmente el tipo de materia, oro, plata, etc., o su peso. Son excepcionales los textos que nos den más detalles, la mayoría de ellos incluidos en el Cantar de los Cantares requiriéndose, para profundizar en su conocimiento, de los hallazgos arqueológicos. Lo que sí aparecen son suficientes datos como para asegurar que la indumentaria femenina y especialmente los aderezos variaban según la posición social, la actividad o el estado de las mujeres, además de sus funciones mágicas, religiosas o sociales.

Así, la total eliminación de joyas, adornos y perfumes era característica de las viudas que llevaban una severa indumentaria indicativa de su

28 Respetamos literalmente la traducción de Cantera, aunque los nombres de algunas prendas de la indumentaria, como estos "chales" o la "mitra" citada más abajo, resultan poco verosímiles pues se asimilán a accesorios modernos que difícilmente se corresponderían con los de la época. 
estado como nos confirma la historia de Judá y Tamar (Génesis 38,14) o la de Judit:

Judit 10, 3 Quitóse el cilicio que llevaba puesto y se despojó de los vestidos de su viudez: Lavó todo su cuerpo, ungióse con perfume espeso, peinó sus cabellos y tocó su cabeza con la mitra, y se vistió los vestidos de su regocijo, con que solía ataviarse en vida de su marido, Manasés. 4 Calzó sus pies con sandalias y se puso los collares, los brazaletes, los anillos y los pendientes y todas sus alhajas, con que se hermoseó extremadamente, hasta cautivar las miradas de cuantos hombres se topasen con ella.

Tanto Tamar como Judit se quitan sus vestidos de viudas y se adornan con la intención de informar al resto de la sociedad que han dado por terminado el periodo de luto, durante el cual se debían abstener de entablar cualquier tipo de relación. En ambos casos, su conducta tiene el propósito concreto de atraer sexualmente a un varón determinado.

Asimismo, como parece lógico, las joyas eran escasísimas entre las mujeres cautivas, cuando eran deportadas o presentaban tributos $u$ ofrendas a otras naciones. El trabajo de Pauline Albenda, "Western asiatic women in the iron age: Their image revealed" ${ }^{29}$, basándose en las imágenes asirias, especialmente en los bajorrelieves de los palacios de Khorsabad, Nimrud y Nínive, fechados entre la novena y la séptima centuria, muestra cómo en cada región se empleaban indumentarias diferentes con tipos de tocados y peinados propios, además de las túnicas más gruesas (de lana) para las norteñas y de lino o algodón para las cautivas meridionales. En las representaciones de fenicias y filisteas que compartían el territorio con las israelitas, éstas aparecen con un alto tocado más o menos cónico, cubierto con un pañuelo o velo, debajo del cual parece apreciarse una diadema sobre la frente. Colgando sobre un hombro llevan una bolsa en la que probablemente estarían sus enseres personales, quizá también algún espejo o aderezo, aunque probablemente todas las joyas, objeto preferente de los botines de guerra, les fueron quitadas. En las representaciones egipcias de israelitas portando presentes a Egipto, éstas sólo llevan una fina diadema como complemento a la túnica y zapatos ${ }^{30}$.

29 Biblical Archaeologist, vol. 46, núm. 2 (Primavera 1983), pp. 82-89.

30 Así aparecen en el fresco de Beni Hasan, fechado en la diecinueveava centuria, donde se representan a cananeos (hombres y mujeres) llevando presentes a Egipto. Más enjoyados van los esclavos, (hombres, mujeres y niños) que aparecen en otro fresco egipcio, donde se pueden apreciar con claridad aros en sus orejas, pero a pesar de su simplicidad, los caracteres negroides de estos esclavos son patentes por lo que no nos parece oportuna su utilización en nuestro contexto. 
Sin embargo, la escasez de recursos o la pobreza no implicaba la eliminación de los adornos personales, aunque en estos casos, las ricas piedras y metales eran sustituidos por cerámica, hueso y cristal, materias ampliamente empleadas para la fabricación de cuentas de collar; bisutería en vez de joyería, si se quiere, pero capaz de cumplir las mismas funciones. El artículo de Elizabeth E. Platt sobre los colgantes de hueso ${ }^{31}$ que con bastante frecuencia se documentan en los yacimientos palestinos de la Edad del Hierro indica que en los lugares donde aparecen estas piezas, no lo hace el oro o la plata. Además la autora, después de analizar una tipología muy abundante (de forma cilíndrica, decorada con círculos y puntos en su interior), que suele aparecer de forma individualizada, acompañado de cuentas de collar, escarabeos y amuletos concluye que debía colgarse de una cuerda, a modo de gargantilla de uso cotidiano. También señala su probable carácter de amuleto, considerando su decoración como una representación del ojo. En mi opinión, el diferente número de símbolos grabados en unos y otros colgantes, quizá podría indicar algún tipo de contabilidad. La lectura del trabajo de Naomi y Edwin ${ }^{32}$ que muestra cómo la representación del ombligo es privativa de las figuras femeninas y normalmente asociada a la fertilidad, ya sea de diosas o

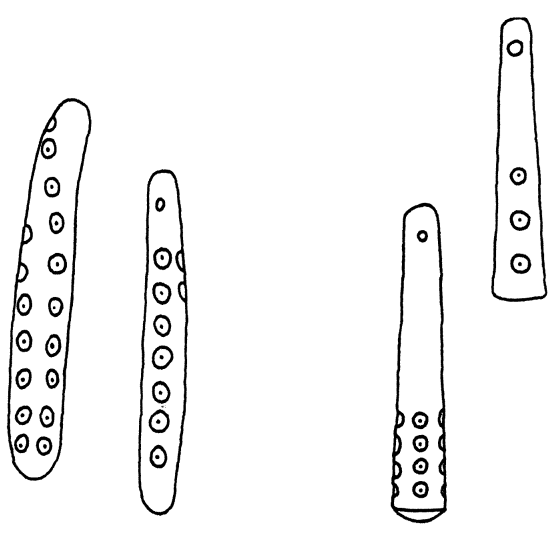

FIG. 3.-Colgantes de hueso con decoración de círculos y puntos. Los de la izquierda proceden de Megiddo y de Samaria los de la derecha. Según Elizabeth E. Platt. de mujeres, nos hace pensar que tal vez sea esto lo que simbolizan los círculos con un punto en su interior, aventurándonos a conjeturar que quizá llevaran la cuenta del numero de faltas en la menstruación y por tanto los meses de embarazo, partos o hijos tenidos, o cualquier otro hecho u objeto de interés femenino (ver fig. 3).

Pero si eliminamos situaciones extremas, las representaciones femeninas suelen aparecer abundantemente enjoyadas. Ya sean jóvenes, desposadas, novias, esposas, prostitutas, sacerdotisas o diosas de la fe-

31 Elizabeth E. PATT, "Bone pendants", Biblical Archaeologist, vol. 41, núm. 1 (Marzo 1978), pp. 23-28.

32 Naomi F. Goldsmith and Edwin Gould, "Sumerian Bats, Lión-headed Eagles, and Iconographic Evidence for the Overthrow of a Female-priest Hegemony", Biblical Archaeologist, vol. 53, núm. 3 (Septiembre 1990), pp. 142-157. 
cundidad, como veremos, todas ellas portan joyas en su indumentaria y, seguramente, la repulsa del profeta Isaías se debía tanto o más, a esta causa que al carácter mágico de algunos aderezos. Como ilustración al tema, tal vez lo más oportuno sea comenzar tratando de las placas de arcilla en las que de manera esquemática se representan mujeres desnudas aunque profusamente enjoyadas, con sus carácteres sexuales exagerados y muchas veces en actitudes obscenas o provocativas, siendo lo más común que se sujeten los pechos con las manos o que porten símbolos de fertilidad y fecundidad como los lirios o la serpiente. Estas placas son numerosísimas en todo el Próximo Oriente ${ }^{33}$, las de los yacimientos palestinos parecen alejarse del modelo de diosa-madre para subrayar sus caracteres sexuales, apareciendo en los templos como ofrendas votivas, en las tumbas donde las joyas de la difunta se sustituyen por su representación y en las viviendas, a modo de amuletos. Más excepcional es el hallazgo de este mismo tipo de representación, realizado en láminas de oro o en colgantes de este metal o de plata. De algunas pocas, por su simbología (por ejemplo: tiara rematada en dos cuernos, representaciones de pie encima de un caballo o un león) o por la inscripción que las acompaña, se puede afirmar con seguridad que representan a diosas del amor sexual, como Astarté, pero en la mayoría de los casos se desconoce si son mujeres o diosas, sacerdotisas, prostitutas divinas, novias, o, simplemente, representaciones simbólicas de los atributos reproductivos femeninos. Lo que sí parece claro es su empleo como amuletos para obtener la fertilidad. Aunque están desnudas y son de gran tosquedad y esquematismo, la aparición de joyas es una constante, normalmente señalando varios collares que cubren parte del pecho, o, a manera de gargantilla, además de la diadema en la frente y complicados y sofisticados tocados, algunos de los cuales incluyen los rodetes (ver fig. 4).

El relato mesopotámico de la bajada de la diosa Isthar a los infiernos, es cita obligada en este apartado. El mito de origen acadio, tomado por los sumerios, se transmitirá hasta la mitología griega con Afrodita y Adonis, siendo hoy conocido por versiones de Asur y Nínive ${ }^{34}$. La diosa Isthar, identificada con Astarté y posteriormente con Afrodita, baja a los infiernos para rescatar a su amante, al traspasar cada una de las siete puertas, el guardián la va despojando de todos sus aderezos:

Cuando por la primera puerta le hizo cruzar, le arrebató y le quitó la gran corona de su cabeza.

33 E. Douglas VAN BUREn, Clay figurines of Babylonia and Assyria (New Haven: Yale University Press, Yale Oriental Series Researches, Volume XVI, 1980)

34 Federico LaRa PeInado, Mitos sumerios y acadios (Madrid: Editora Nacional, 1984), pp. 402 y ss. 

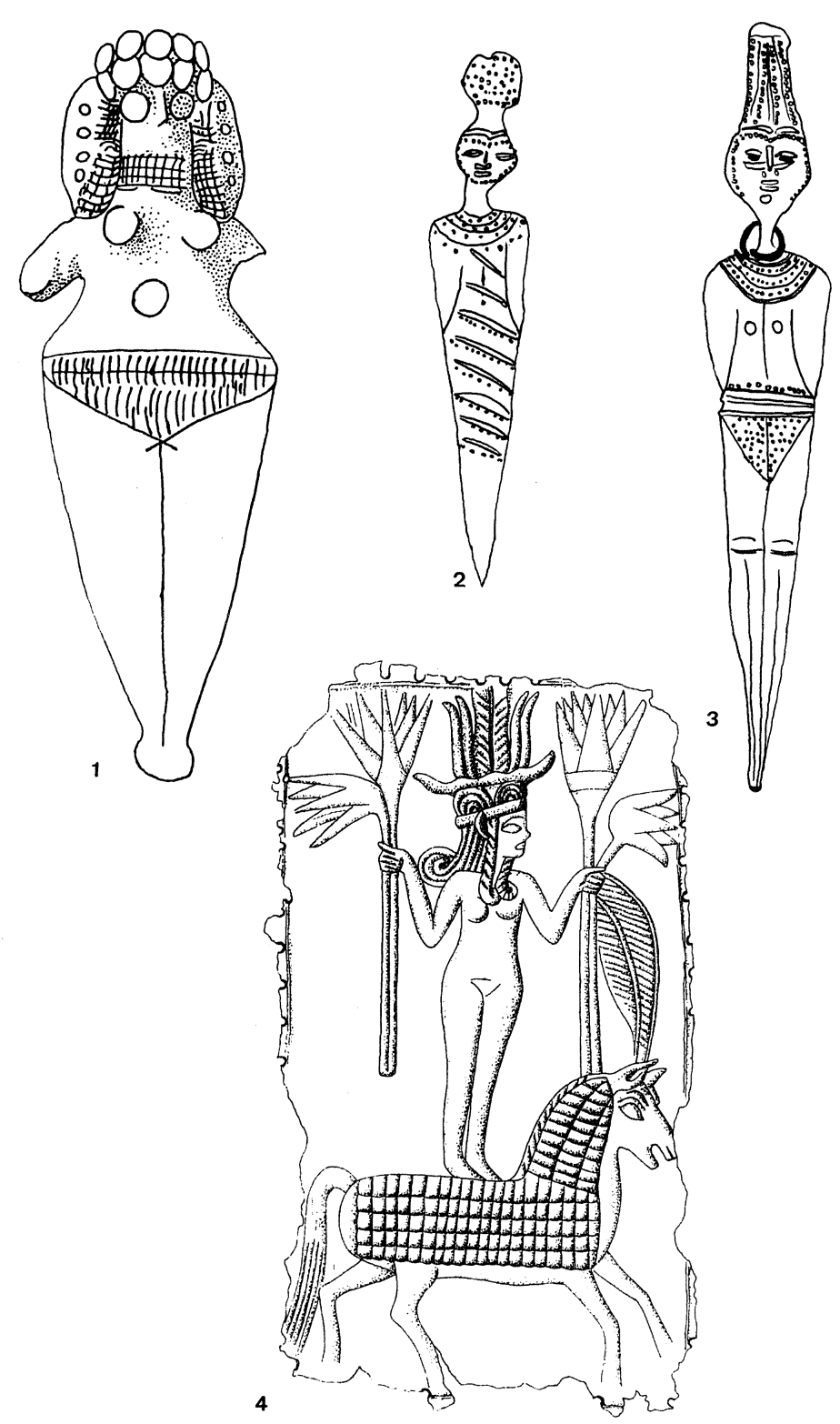

FIG. 4.1.—Prostituta divina" de procedencia desconocida datada alrededor del 1700 a.C., Irak Museum. Dibujo de Marilyn Schnider. 2 y 3.-Láminas de oro representando figuras femeninas, recuperadas del escondite de una vivienda en el yacimiento de Gezer y datadas en la dieciseisava centuria (dibujo de la autora sobre fotografía). 3.Placa de oro representando a una diosa cananea, recuperada del templo cananeo de Tell Lachish, fechada en la treceava centuria. Dibujo de Florica Vainer, Israel Museum. 
"¿Por qué, oh portero, has quitado la gran corona de mi cabeza?"

"Pasa, señora mía, así son las reglas de la Señora del Mundo Inferior"

Cuando por la segunda puerta le hizo cruzar, le arrebató y le quitó los pendientes de sus orejas.

"¿Por qué, oh portero, has quitado los pendientes de mis orejas?"

"Pasa, señora mía, así son las reglas de la Señora del Mundo Inferior"

Cuando por la tercera puerta le hizo cruzar, le arrebató y le quitó las cadenas de su cuello.

"¿Por qué, oh portero, has quitado las cadenas de mi cuello?"

"Pasa, señora mía, así son las reglas de la Señora del Mundo Inferior"

Cuando por la cuarta puerta le hizo cruzar, le arrebató y le quitó los adornos de su pecho.

"¿Por qué, oh portero, has quitado los adornos de mi pecho?"

"Pasa, señora mía, así son las reglas de la Señora del Mundo Inferior"

Cuando por la quinta puerta le hizo cruzar, le arrebató y le quitó el ceñidor de piedras de alumbramiento de sus caderas.

"Por qué, oh portero, has quitado el ceñidor de piedras de alumbramiento de mis caderas?"

"Pasa, señora mía, así son las reglas de la Señora del Mundo Inferior"

Cuando por la sexta puerta le hizo cruzar, le arrebató y le quitó las abrazaderas de sus manos y pies.

"¿Por qué, oh portero, has quitado las abrazaderas de mis manos y pies?"

"Pasa, señora mía, así son las reglas de la Señora del Mundo Inferior"

Cuando por la séptima puerta le hizo cruzar, le arrebató y le quitó el taparrabos ${ }^{35}$ de su cuerpo.

"¿Por qué, oh portero, has quitado el taparrabos de mi cuerpo?"

"Pasa, señora mía, así son las reglas de la Señora del Mundo Inferior"

Se trata del precedente más antiguo que conocemos de la descripción pormenorizada de las prendas y partes de la mujer, también recogido, como veremos en el Cantar de los Cantares. Este recurso ha sido muy empleado hasta nuestros días en la literatura de tradición oral. La diosa iba desnuda, pero cargada de joyas y aderezos ajustándose a la iconografía de las placas de arcilla y metálicas. Las representaciones de figuras enjoyadas nos dan una de las claves para la interpretación del empleo de joyería femenina que es su profunda e indisoluble ligazón a la actividad sexual. Si de forma mayoritaria la mujer es la portadora y poseedora de los adornos y joyas cotidianas, son los hombres quienes las encargan, compran y regalan, normalmente como paso previo a entablar cualquier tipo de relación:

Ezequiel 23,40 [...] Por ellos te lavaste, te alcoholaste los ojos y te adornaste con aderezos; 41 te reclinaste sobre un lecho precioso ante el cual había una mesa

35 Federico Lara traduce el término original por "camisón", añadiendo en nota a pie de página que se trataba de la prenda más íntima femenina parecida a un taparrabos, palabra, a nuestro juicio, mucho más afortunada que se ajusta puntualmente a la indumentaria que muestran las abundantes imágenes femeninas de terracota. 
dispuesta, y pusiste sobre él mi incienso y mi óleo; 42 [...] y en medio de esta turba de hombres llegaron los bebedores del desierto, que pusieron ajorcas en las muñecas de ellas y una corona magnífica sobre sus cabezas [...] 44 Y llegáronse a ella como se llega a una mujer prostituta [...]

Pero no sólo se enjoya a las prostitutas, su papel es aun más importante durante los esponsales y la boda, que es cuando se reciben esas dádivas en mayor cantidad, luciéndose posteriormente de forma habitual ante el esposo: Isaías 61, 10 [...] "y cual una esposa que se adorna con su aderezo." Así nos lo confirma el relato de los desposorios de Isaac y Rebeca:

Génesis 24, 22 Ahora bien cuando los camellos acabaron de beber, tomó el hombre un anillo de oro de un béqa de peso y dos ajorcas que pesaban diez siclos de oro para las muñecas de ella; [...]

29 Tenía Rebeca un hermano llamado Labán, [...] y en cuanto vió el anillo y las ajorcas en las muñecas de su hermana y oyó las palabras de su hermana Rebeca: "Así me ha hablado el hombre", se fue a éste, [...] 31 y le dijo "Ven, bendito de Yahveh [...]

47 [...] En seguida le he puesto el anillo en la nariz y las ajorcas en las muñecas. [...] 52 Cuando oyó el criado de Abraham las palabras de aquellos, se prosternó ante Yahveh rostro en tierra. 53 Luego sacó objetos de plata y objetos de oro y vestidos y se los dio a Rebeca, entregando también valiosos presentes a su hermano y a su madre.

Bastó a Labán ver el anillo y las ajorcas para saber el propósito del criado de Abraham. Además, al constituir estos regalos parte del precio de la novia, es necesario saber su peso que, traducido a nuestro sistema, sería de 8,25 gms. para el anillo y 165 gms. para las pulseras ${ }^{36}$. De la época solo conocemos un ejemplar de anillo para la nariz que estaba depositado en la Tumba de la Princesa: de forma circular, truncada por un lado, tiene una decoración en zigzag realizada con finísimo granulado ${ }^{37}$, aunque no corresponde a nuestra área de estudio, sino a Ebla, ciudad al norte de Siria. En otra referencia a los esponsales de carácter alegórico, se repiten el anillo de la nariz y las ajorcas, añadiendo otras joyas:

Ezequiel 16, 8 Y pasé junto a ti y te vi, y he aquí que estabas en tu momento, momento de amores, y extendí el borde de mi manto sobre ti [...] y fuiste mía. 9 Y te lavé con agua, te limpié la sangre de encima y te ungí con óleo; 10 te vestí de

36 El siclo y la béqa son una medidas de peso, que asociadas al oro o la plata se empleaban como unidades de intercambio, antes de la acuñación de la moneda.

37 Paolo MATTHIAE, "New Discoveries at Ebla: The Excavation of the Western Palace and the Royal Necropolis of the Amorite Periodn, Biblical Archaeologist, vol. 47, núm. 1 (Marzo 1984), pp. 18-32. 
recamado, te calcé de piel de tajas, te ceñi de lino fino y te cubrí de seda; 11 te adorné con joyas, puse ajorcas en tus muñecas y collar en tu garganta; 12 y coloqué anillo en tus narices, en tus orejas pendientes y corona magnífica en tu cabeza.

Aunque sin duda los relatos más pormenorizados y las metáforas sobre joyería más bellas se encuentran en el Cantar de los Cantares, del que hoy se discute su interpretación alegórica, la boda entre Dios y el pueblo de Israel, para darle un sentido más literal, como los amores del rey Salomón hacia una pastora, la boda de una pareja ${ }^{38}$, etc. A partir de las menciones contenidas en este texto trataremos de profundizar en los tipos y formas de las joyas femeninas. Comenzando por la cabeza, contamos con varias alusiones, no siempre fáciles de interpretar: Cantar de los Cantares 7, 5 "Tu cabeza se yergue como el Carmelo, / y la cabellera de tu cabeza es como púrpura: un rey está prendido en las trenzas".

En nota a pie de página, Francisco Cantera añade la traducción de Zolli al último versículo que puede colaborar a aclarar su sentido: "Tu cabellera superior es como el Carmelo, y la cabellera tuya que cae sobre las espaldas es cual púrpura real ligada en torno a canillas de tejedor".

La comparación de la parte superior del tocado con un monte resulta perfectamente ajustada y comprensible ya que las formas cónicas, más o menos elevadas y con su vértice redondeado estaban y están muy extendidas en esta prenda, pero el final del verso, mas si tenemos en cuenta la disparidad entre las dos posibles traducciones, resulta oscuro, quedando sólo patente la adición de alguna materia de color púrpura al cabello que queda ligado con ella. Otro verso nos ayuda a su comprensión: Cantar de los Cantares 4, 3 "cual mitades de granada son tus sienes / a través de tu velo ${ }^{39}$. A nuestro juicio probablemente está describiendo dos rodetes laterales en los que se recogían sendas trenzas, ajustadas con agujas que, a su vez, se rematarían en una pieza de coral u otra materia de color encarnado. Su asimilación a las mitades de granada es especialmente gráfica e indicativa, ya que este fruto se ha considerado un símbolo de fertilidad. Rodetes de este tipo, más o menos grandes, en la península ibérica son frecuentes tanto en la zona valenciana como en Castilla y están documentados para la época y área del Antiguo Testamento, en las figuritas femeninas de arcilla.

Sin embargo, no hemos encontrado en el Cantar ninguna alusión que con certeza pudiera indicarnos el uso de diadema o corona de cuyo ex-

38 Emilia FERnÁNDEZ TEjERO (Traducción y comentario), El Cantar más bello. Cantar de los Cantares de Salomón (Valladolid: Ed. Trotta/CSIC, 1994).

39 Este verso se repite a modo de estribillo en 6,6. 
tendido empleo tenemos sobradas muestras documentales e iconográficas. La ausencia de corona queda justificada por el alto tocado. Además, ésta joya era empleada como símbolo de poder por reinas (Ester 1,11) y diosas, casi exclusivamente, aunque también a las mujeres preparadas para la vida sexual, novias y prostitutas, se les tocaba con "magnífica corona" (Ezequiel 16,9 y 23,42). Como cabría esperar para tan rica pieza, no se ha conservado ninguna hasta nuestros días. Más información tenemos sobre las diademas que, a modo de banda sobre la frente eran compatibles con los sofisticados tocados. En las representaciones femeninas es casi una constante la aparición de esta pieza, a la que generalmente se añade una hilera de piedras preciosas o semipreciosas, consideradas aquí como representaciones de granos de cereal y por tanto símbolos de fertilidad y fecundidad, además de resaltar su carácter de joya frente a las que probablemente también se usaban de tejido (ver fig. 5). De todos modos el único ejemplar que ha llegado a nuestros días, no se ajusta a este prototipo difundido iconográficamente, sino que está compuesto por una banda de oro con la única decoración hecha por medio de incisiones, de una triple línea en zigzag ${ }^{40}$. Está partida en dos secciones que se unían con una aguja, también de oro (fue depositado en una tumba de Tell El-Ajjul). Este modelo, asimismo, es conocido por algunas figurillas femeninas de arcilla como la fabricada a partir del hallazgo de un molde por Miss Cecil Western ${ }^{41}$.

Sí nos da el Cantar noticia de los pendientes: Cantar de los Cantares 1, 9 "Bellas son tus mejillas entre los zarcillos, / tu cuello entre los collares de corales. 10 Harémoste zarcillos de oro / con puntos de plata." Estos zarcillos debían ser bastante grandes cuando flanqueaban las mejillas. En la
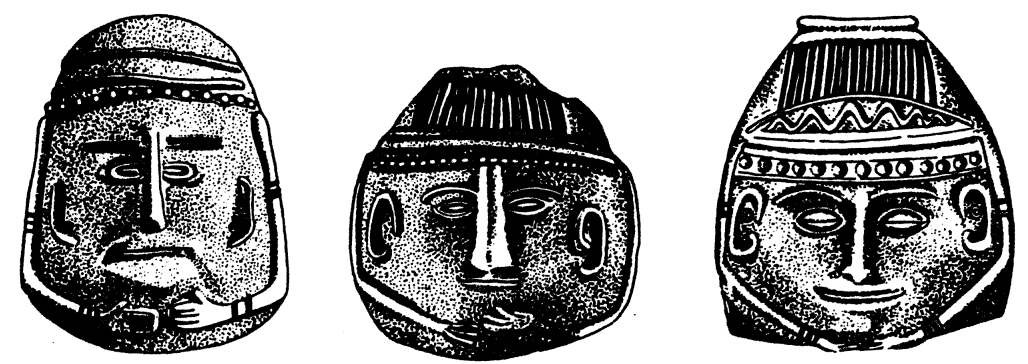

Fig. 5.-Tapas de sarcófagos procedentes de Beth-Shean, tomado de G. Ernest WRIGHT, "Philistine Coffins and Mercenaries", Biblical Archaeologist, XXII, 3 (Septiembre 1959), p. 55.

10 Bradford D. KelleHER, op. cit., pp. 126-127.

"1 Paul W. LAPP, "Taanach by the Waters of Megiddo", Biblical Archaeologist, vol. XXX, núm. 1 (Febrero 1967), p. 24. 
figura 6 se muestran varios tipos de pendientes, todos de oro, procedentes de dos enterramientos de Deir El- Balah ${ }^{42}$ (Bronce Final). Los más simples (números, $2,3,4$, y 5), de contorno amorcillado responden a un prototipo muy extendido y debían llevarse cotidianamente, como nos confirman las constantes alusiones halladas en el texto sagrado. Su forma se considera, igual que la del primer ejemplar de la figura 6 , mucho más elaborada y con decoración de filigrana en su parte más ancha, como representaciones del creciente lunar, totalmente extendidas en la joyería mediterránea. Probablemente a estas joyas se refería el profeta Isaías al mencionar las "lunetas" en el texto con el que iniciamos este apartado (Isaias 3,18). En esta época se consideraba como un símbolo de deidades femeninas de la fertilidad y la vida tanto humana, como vegetal y animal, del tipo Astarté. Las mujeres los llevarían a modo de amuletos protectores o proporcionadores de fecundidad. Así nos lo confirma el hecho de que Jacob, cuando decide eliminar de su familia todos los símbolos u objetos que indicaran idolatría, hace que sus mujeres le den, además de los terafim (ídolos familiares), los pendientes de sus orejas (Génesis 35, 2). También el hecho de que los niños y niñas llevaran pendientes, probablemente del tipo más sencillo, parece confirmar su carácter de amuletos (Éxodo 32, 2). Pero a esta función hay que añadir su reutilización y posterior empleo como "moneda" para las transacciones comerciales antes de que se comenzara la acuñación (siglo IV a. C. en Grecia), lo que está claramente documentado en la época helenística, con ejemplares idénticos realizados en plata ${ }^{43}$ y confirmado, aunque con otra joya, por un texto: Job 42, 11 «Y vinieron a él todos su hermanos y todas sus hermanas [...] y le compadecieron y consolaron [...] y le dieron cada uno una moneda y un anillo de oron.

Siguiendo con los modelos representados en la figura 6, el pendiente con un colgante en forma de fruto o flor es corriente en Canaán durante el Bronce Final e inicios de la Edad del Hierro y raro en los países vecinos, lo que indica con claridad su fabricación local. Por fin, sobre la última alusión a los pendientes del Cantar, "harémoste zarcillos de oro con puntos de platan, Francisco Cantera añade otras posibles traducciones de los "puntos" tales como "glóbulos, gotas, bolitas y puntas" ${ }^{44}$. A nuestro juicio se trata, desde luego, de bolitas, aludiendo a la técnica de granulado

42 Trude DOTHAN, Excavations at the cementery of Deir El-Balab (Jerusalem: Qedem Monographs of the Institute of Archaeology, The Hebrew University of Jerusalem, 10, Ed. Board, 1979).

43 H. C. KeE and L.E TOOmBS, "The Second Season of Excavation at Biblical Shecchem", Biblical Archaeologist, vol. XX, núm. 4 (Diciembre 1975), pp. 82-105.

in Según Antonio Cea, en el glosario empleado aún hoy por los plateros salmantinos se denomina pezuelo o pezuelos a esta guarnición. 
que, aunque era conocida desde tiempos muy remotos (se ha documentado en pulseras y anillos de la XVII centuria a.C.), por su laboriosidad (el metal debía ser reducido a estas minúsculas esferas que luego se soldaban una a una, formando la decoración) con frecuencia era sustituida por un punteado realizado con buril, a modo de repujado, sobre las láminas
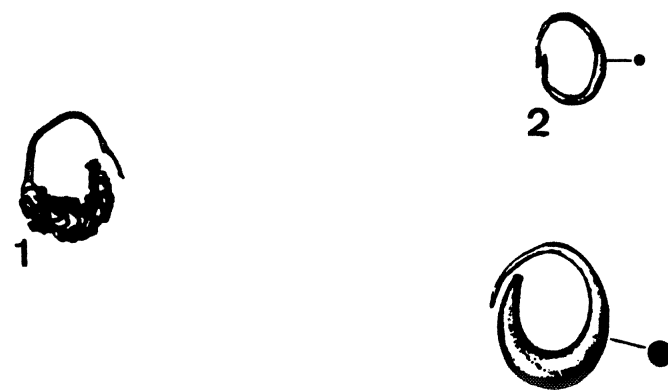

4
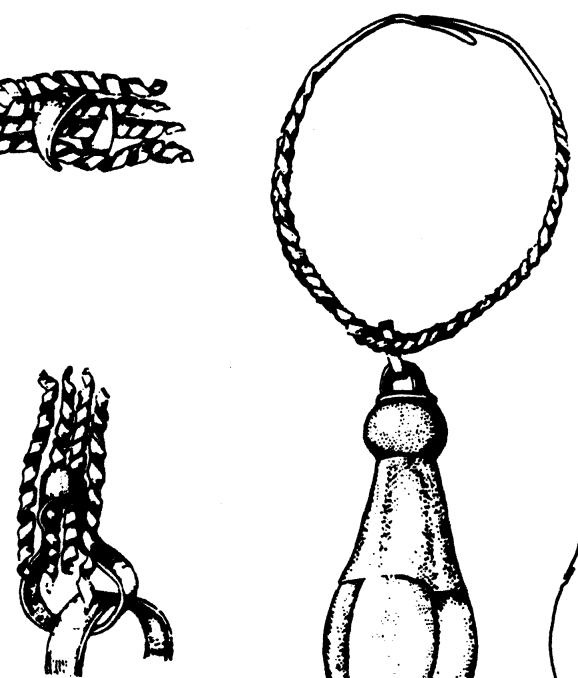

6

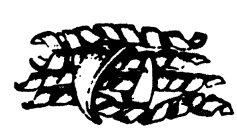

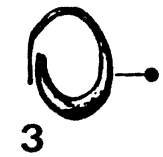

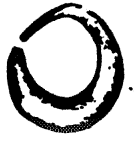

5

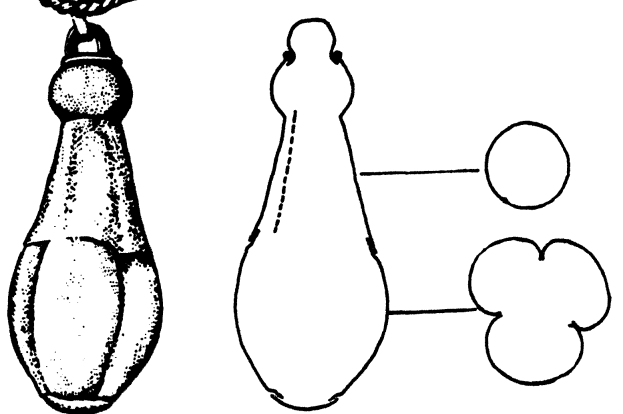

FIG. 6.-Pendientes procedentes del yacimiento Tell El-Ajjul, recuperados en las tumbas de Deir El-Balah (Bronce Final, aproximadamente treceava centuria a.C.) según Trude DOTHAN, 1979. 
metálicas. La mencionada alternancia de oro y plata no está documentada histórica o arqueológicamente ni aquí, ni, hasta donde sabemos, en ningún otro país, pero con esta alusión, sin duda, se querría resaltar que se trataba de un verdadero granulado y no de una imitación repujada. Procedentes de Tell El-Ajjul se conservan pendientes de oro, en forma de creciente lunar y con rica decoración de finísimo granulado ${ }^{45}$.

El plural empleado en la alusión a los "collares de corales" es plenamente correcto, pues normalmente no se llevaba uno, sino varios de distinta longitud (en las muestras iconográficas, las mujeres suelen aparecen con tres) que cubrían la parte superior del pecho y el cuello. Sin embargo, los hallazgos arqueológicos nos dan sobrados ejemplos sobre la ausencia de joyas de coral, mientras son abundantísimas las de cornalina o cornelina $^{46}$ (tipo de ágata de tonalidad roja que oscila entre las más claras y traslúcidas, al rojo sangre e incluso más oscuro). A la cornalina que debe su nombre a su semejanza con el coral, con toda probabilidad se le atribuían las mismas funciones o propiedades de tipo mágico que a ésta piedra. Otras materias empleadas para las cuentas son, según los hallazgos arqueológicos, además del oro y plata, piedras preciosas o semipreciosas como lapislázuli, ónice, ágata, ámbar, cristal y cerámica, aunque los relatos bíblicos amplían y enriquecen la lista, añadiendo: Bedelio (Génesis, 2,8), ¿piedra de sóbam? (Génesis, 2,8; Éxodo 35,17), los rubíes (Ezequiel 27,16; Isaías 54,11; Eclesiástico 32,5), carbunclos (Isaías, 54,11; Ezequiel 27,16; Ezequiel 28,13), zafiros (Éxodo 24,10; Ezequiel 28,13), malaquita (Isaias 54,11), esmeraldas (Eclesiástico, 32,5; Ezequiel 28,13), esmeraldinas (Ester 1,6), ¿"gotas"? (Josué 6, 26), sardónices (Ezequiel 28,13), topacios (Éxodo 28,17 y Ezequiel 28,13), jaspes (Éxodo 28,17 y Ezequiel 28,13), crisólitos (Ezequiel 28,13), ágata (Éxodo 28,17), amatista (Éxodo 28,17) y berilo (Ezequiel 28,13), aunque no se relacionan necesariamente con los collares sino con la orfebrería en su sentido más amplio. Las formas de las cuentas más extendidas son redondas, tubulares, bicónicas, agallonadas,

45 Bradford D. Kelleher, op. cit., p. 124. Según Avraham NeGEv, op. cit., pp. 172-173, otros pendientes de este tipo procedentes del mismo yacimiento se encuentran en el Museo Rockefeller, entre éstos últimos hay un ejemplar, con repujado en vez de granulado que muestra en su borde interior la cabeza de un pájaro, modelo frecuente en los pendientes. Este detalle puede ayudarnos a comprender la traducción de Emilia FERNÁNDEZ TEJERO, op. cit., p. 14 que traduce por tórtolas la palabra que Francisco Cantera denomina zarcillos.

46 La identificación de las piedras preciosas mencionadas en el Antiguo Testamento, es, en muchas ocasiones, poco fiable, siendo frecuente que Francisco Cantera ofrezca varias alternativas empleadas en unas $\mathrm{u}$ otras ediciones de la Biblia, lo mismo ocurre con la nomenclatura de joyas y aderezos. 
y de seudobarril; también se encuentran otras de tipo figurativo como las semillas de loto. Un verso del Cantar de los cantares nos confirma que, como también ocurre en la actualidad, las materias empleadas en la joyería eran seleccionadas por los poderes que se les atribuían: 4, 9 "Me robaste el corazón, hermana mía, esposa; / me robaste el corazón con una sola mirada de tus ojos, con un sólo sartal de tu cuello" ${ }^{47}$ (ver fig. 7).

Ya vimos antes cómo la diosa Isthar, en su bajada a los infiernos llevaba un cinturón o ceñidor con piedras de alumbramiento que nos vuel-
, I \&ी की व
2
por
(0)
(2)
๑ $=$
3
(0) 49
(0)
() 0
4
(9)
0
⿷
(2) 0

5
(ㅇ) 0
(2) $0=$

E.

$00 \square$

6

(C)

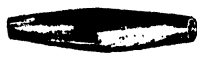

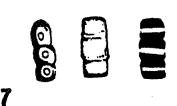

๑) $\infty=$

() $0:$

()ㅇ 0

FIG. 7.1.-Cuentas de cornalina en forma de semilla de loto. 2-5.-Cuentas de cornalina y otras piedras semipreciosas. 6.-Cuentas de oro. 7.-Cuentas de cerámica. Tell El-Ajjul, recuperados en las tumbas de Deir El-Balah, según Trude Dothan, 1979.

17 Otras posibles traducciones añadidas en una nota a pie de página en la edición de Francisco Cantera son un cabello o rizo de tu cuello", "una sola perla de tu collar" y un simple dije de tu collar" a las que habría que añadir la de Emilia FERNÁNDEZ TEJERO, op. cit., "una sola cuenta de tu collar". 
ve a confirmar el carácter mágico atribuido a determinadas piedras que podían emplearse como en el Cantar, para despertar el amor de un hombre, o como en el mito sumerio para tener un buen parto, etc. Cuando, la diosa, totalmente desprovista de sus joyas y amuletos pasa a los infiernos, pierde sus poderes quedando indefensa y también ella es atrapada. Pero las propiedades mágicas de las cuentas de los collares no eran suficientes por lo que era normal la adición de dijes y amuletos. Las funciones sexuales o amorosas de éstos también está recogida:

Oseas 2, 2 Aparte de sus signos de fornicación de su rostro / y sus señales de adulterio de entre sus pechos, [...]

13 Y castigaré en ella los días consagrados a los Baales, / a quienes quemaba incienso,

mientras se ataviaba de sus arillos y collares, / y andaba tras sus amantes

El primer verso alude al velo que normalmente portaban tanto las prostitutas como las novias, mientras que el segundo se refiere a los colgantes a los que se atribuían propiedades relacionadas con la vida sexual. Como siempre, mucho mas liberal y bella es la alusión contenida en el Cantar de los cantares: 4, 4 "Como la torre de David es tu cuello, / edificada para trofeos; mil escudos penden de ella, / todos paveses de héroes" (ver fig. 8).

La metáfora resulta especialmente gráfica y adecuada para los dijes o colgantes de oro y plata, tanto por su forma, más o menos ovoide, similar a la de los escudos como por los destellos metálicos. Colgantes de este tipo están bien documentados; algunos vuelven a reproducir las imágenes de deidades femeninas desnudas pero enjoyadas que ya hemos visto en placas de arcilla y oro ${ }^{48}$. Otros representan estrellas de ocho o seis puntas ${ }^{49}$, aves, o, como los de oro o cornalina, reproducidos en la figu-

18 Responde a este esquema el colgante de oro que representa a la diosa Asherah de pie sobre un león, desnuda pero con corona y collares y flanqueada por serpientes y aves. Encontrada en Ugarit se fecha alrededor del 1350 a.C., ver David NOEL FEEDMAN, "Yahweh of Samaria and His Asherah", Biblical Archaeologist, vol. 50, núm. 4 (December, 1987), p. 243. Más difundido, un colgante de oro procedente de Tell ElAjjul, representa a la diosa egipcia Kathor, mientras que en otro, también de oro, procedente de Beth Shean, y datado en la catorceava centuria a.C., de clara influencia egipcia pero de fabricación cananea, el ¿cetro? que la figura lleva en una mano nos indica su carácter de deidad. Para los dos últimos véase entre otras publicaciones Bradford D. KelLeHER, op. cit., pp. 123 y 127 respectivamente.

i9 En la obra de Kelleher, de la cita anterior se recogen dos ejemplares de colgantes con representación de estrella de ocho puntas, hechos en oro repujado con incisiones y asimismo procedentes de Tell El-Ajjul. Mucho más bellos son colgantes con estrellas de seis puntas que penden de la gargantilla de oro encontrada en la tumba del Señor de las Cabras: Paolo MATTHIAE, op. cit., p. 27, aunque probablemente se trata de un collar masculino, además de corresponder al norte de Siria. 

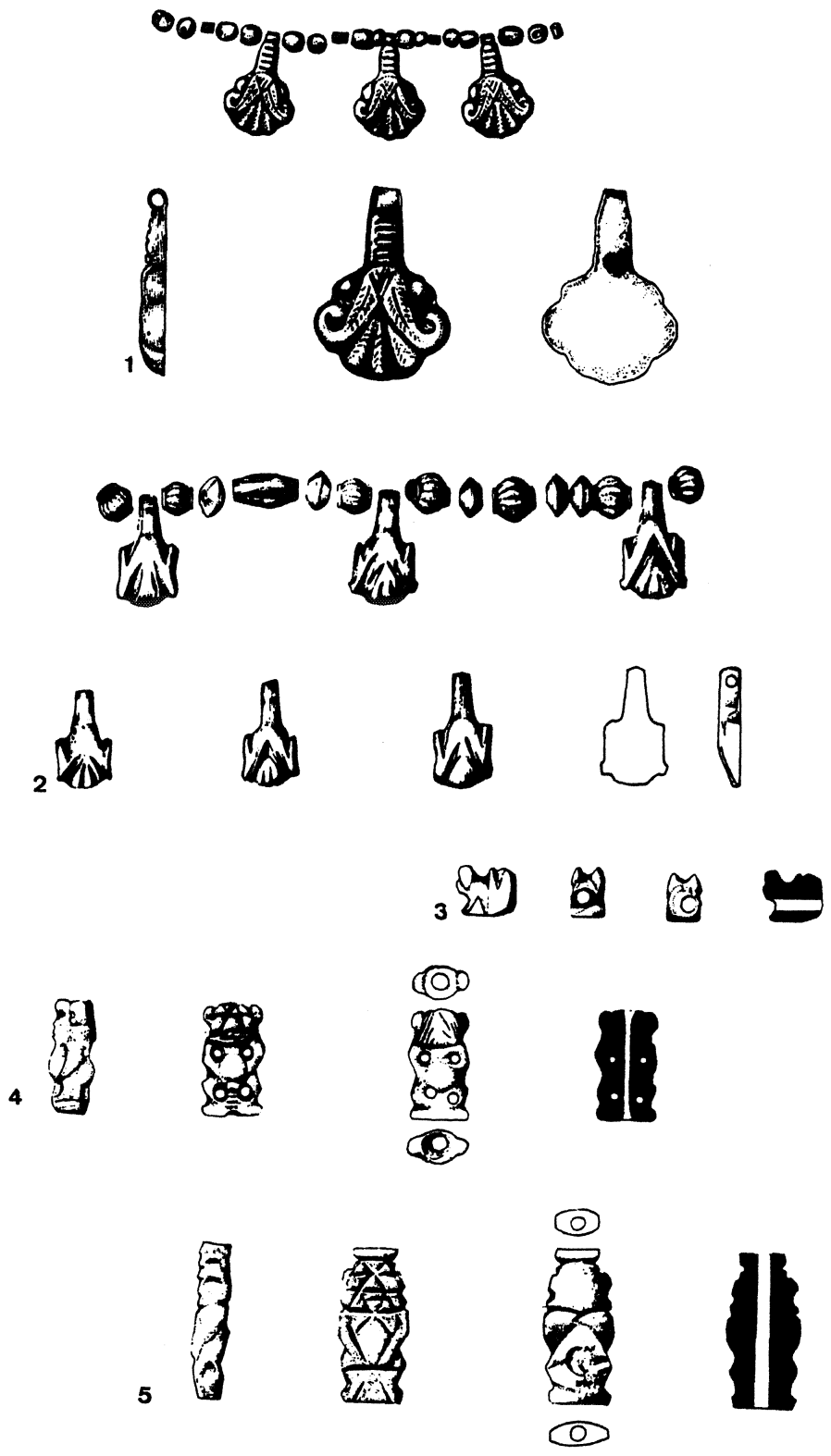

FIG. 8.1.-Collar con cuentas de oro, cornalina y colgantes de oro en forma de palmeta. 2.-Collar con cuentas de oro, cornalina y colgantes en forma de palmeta de cornalina. 3.-Amuleto del dios Bast en forma de gato de cornalina. 4.-Amuleto del dios Ptah-Sokar de cornalina. 5.-Amuleto del dios Bes de cornalina. Yacimiento Tell El-Ajjul, recuperados en las tumbas de Deir El-Balah, según Trude Dothan, 1979. 
ra 8, la extendidísima palmeta de cinco puntas de origen egipcio. Entre los últimos, los realizados en oro iban pigmentados de rojo o negro cubriendo toda su superficie, algo rarísimo en la antigüedad. Antonio Cea nos sugirió que la forma en palmeta de cinco puntas podría asimilarse a la representación de la higa o de la mano de Fatma, amuletos totalmente difundidos en el ámbito mediterráneo pasado y presente. La cornalina será la otra materia preferente para los colgantes a modo de amuletos, a veces representando deidades, como los de la figura 8, o también frecuentemente en forma de escarabeos. En cualquier caso conviene tener presente que, en más de una ocasión, no es posible discernir si determinado colgante formaba parte de un pendiente de oreja, de un collar, un cinturón, o si se llevaba de forma independiente, suspendido de una cuerda o cadena. Sólo con las joyas encontradas en sepulturas excavadas con criterios modernos, por el lugar donde aparecen (junto al cuello, en la cintura, etc.), se puede conjeturar a que tipo de pieza pertenecieron e intentar su reconstrucción.

Pero todavía hay más aderezos cubriendo el pecho de las mujeres: Cantar de los cantares 1, 12 "Bolsita de mirra es para mí mi amado,/ que entre mis pechos descansa." Por numerosas citas anteriores podemos hacernos una idea de la enorme importancia que tenían los perfumes dentro de la indumentaria femenina, siempre asociados a las joyas. Según se desprende del verso anterior, las mujeres llevaban una bolsita o garnielillo con mirra, colgada del cuello. También la cita de Isaías con la que iniciamos este apartado mencionaba los frascos de perfume (Isaias 3,20) que podrían ser una versión lujosa de este accesorio cotidiano. Sin embargo, según Frazer ${ }^{50}$, la expresión literal en hebreo que no parece en ningún otro pasaje de la Biblia es "casas del alma" que san Jerónimo tradujo por cajas de perfumes o frascos de aromas, acepción que ha sido seguida en ediciones posteriores. También Frazer nos informa, cómo en el Antiguo Testamento existía la posibilidad de desprenderse temporalmente del alma y guardarla en un lugar seguro o que ésta fuera atrapada por las brujas, concluyendo que resulta totalmente factible que se creyera que un recipiente destinado al perfume fuera su lugar de alojamiento extracorporal. $\mathrm{Si}$ tenemos en cuenta las enormes afinidades y paralelos existentes en toda la joyería del mediterráneo, pasada y presente, puede resultar de interés saber que, como ha estudiado Antonio Cea, en la indumentaria tradicional de la Sierra de Francia (Salamanca), se denomina alma al interior de las joyas y estaba extendida la costumbre de introducir torcidas de lana o

50 James George Frazer, El Folklore en el Antiguo Testamento (México: Fondo de Cultura Económica, 1981), p. 338. 
lino perfumadas o hierbas aromáticas en algunos tipos de cuentas o colgantes, especialmente en las bolas de filigrana. Aunque no procedentes de Palestina sino de Chipre, se han encontrado pequeños colgantes de oro con forma de anforitas, destinados a contener perfumes; su tipología nos puede resultar familiar por las de los collares que adornan el pecho de la Dama de Elche.

Otras joyas femeninas bien documentadas por los textos y los hallazgos arqueológicos son las ajorcas para brazos y pies. El empleo del plural es plenamente deliberado pues normalmente se llevaban varias en cada extremidad, con el propósito de que los movimientos corporales provocaran su tintineo. Al ruido metálico se le atribuían y atribuyen propiedades mágicas como ahuyentador de demonios y malos espíritus, además de su carácter de provocación o incitación sexual cuando procede de los adornos que portan las mujeres y que tanto enfurecía al profeta Isaías. Los largos brazos que parten de la parte superior de la cabeza, en las tapas de los sarcófagos de la figura 5 muestran ajorcas o manillas en el antebrazo y brazo, mientras que las instrumentistas de la figura 9 además de varios brazaletes en ambas muñecas, los llevan también en su tobillo derecho. Un conjunto de cuatro de estos ejemplares en oro, de sección cilíndrica y bastante abiertos en su extremo forman parte de la joyería encontrada en un tesoro doméstico de Tell El-Ajjul ${ }^{51}$. Mientras que otro,

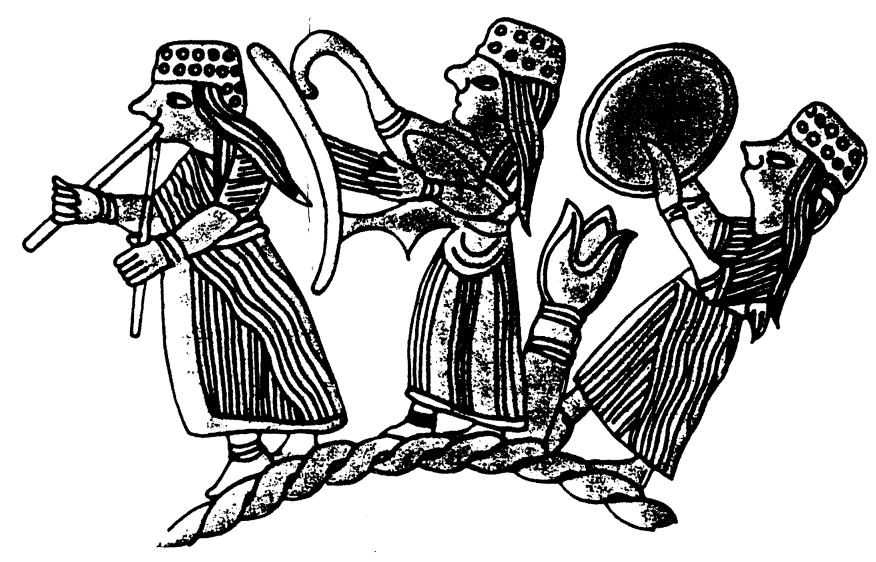

FIG. 9.-Grupo de músicas conocido como "orquesta fenicia", reproducido en un cuenco de plata encontrado en Chipre, Museo Británico, tomado de Carol L. MEYERS, "Of Drums and Damsels: Women's Perfomance in Ancient Israel", Biblical Archaeologist, vol. 54, núm. 1 (Marzo 1991), p. 18.

51 Bradford D. KelleHER, op. cit., p. 124. 
todavía más antiguo (el yacimiento citado se fecha en la mitad del segundo milenio a.C., mientras que la necrópolis de Ebla, al norte de Siria, lo hace alrededor del 1700 a.C.) compuesto por seis pulseras de oro torcidas en espiral, decoradas con granulado y con sus extremos aguzados y muy próximos fue depositado en la Tumba de la Princesa ${ }^{52}$. También está confirmado el empleo en solitario de una pulsera o brazalete, existiendo un bello ejemplar de bronce procedente de Tell el-Hesi ${ }^{53}$ y fechado en el Bronce Inicial. Esta pieza, además de torcerse en espiral se remata en uno de sus extremos con la cabeza de una serpiente.

Hemos dejado sin tratar algunas joyas femeninas como los anillos, los sellos, o las pinzas y fíbulas que también caracterizan la indumentaria masculina y será en ese apartado donde las contemplemos.

\section{LAS JOYAS Y ORFEBRERÍA MASCULINAS COMO SÍMBOLOS DE PODER}

Si, como hemos visto, la joyería femenina se asocia de forma preferente a su disponibilidad para la vida sexual y la fertilidad, la masculina suele constituir un símbolo de poder. Se trata de signos distintivos de la élite dominante, señalando un determinado status preeminente. Así, en la cúpula jerárquica, las expresiones "ceñirse la corona, o la diadema", son las comúnmente empleadas para indicar el dominio de un rey sobre un determinado territorio:

2 Samuel [El rey Saúl pide que le rematen tras caer mortalmente herido] 1, 10 Lleguéme, pues, a él y le rematé, pues comprendí que no había de sobrevivir a su caída. Luego tomé la diadema que llevaba en la cabeza y el brazalete de su brazo y los he traído a mi señor, aquí.

2 Samuel 12, 29 Reunió, pues, David a todo el pueblo y partió hacia Rabbá, la combatió y se apoderó de ella. 30 Entonces tomó la corona de Malkam de sobre la cabeza de éste. El peso de aquélla era de un talento de oro y estaba guarnecida de una piedra preciosa, y fue colocada sobre la cabeza de David.

I Macabeos 11, 13 Entró Tolomeo en Antioquía y ciñó su cabeza con la diadema de Asia, poniendo así sobre su cabeza dos diademas: la de Egipto y la de Asia [...] 11, 54 Después de esto volvió Trifón, trayendo consigo al joven niño Antíoco; le proclamó rey y ciñóle la diadema.

I Macabeos 12, 39 Trifón aspiraba a reinar sobre Asia y ceñirse la diadema quitando la vida del rey Antíoco. [.....] 13, 31 Trifón, procediendo dolosamente con el joven rey Antíoco, le mató; 32 reinó en su lugar y se ciñó la diadema de Asia, causando así una gran calamidad sobre el país.

52 Paolo MATTHIAE, op. cit., pp. 18-32.

53 Valerie M. Fargo and Kevin G. O'Connell. S. J., "Five Seasons of Excavation at Tell el-Hesi", Biblical Archaeologist, vol. 41, núm. 4 (Diciembre 1978), p. 173. 
Sabiduria 18, 24 [Refiriéndose a Aarón, el primero de los sumos sacerdotes israelitas, designado por Dios] Pues en su vestidura talar estaba todo el universo/ y las glorias de los padres en las cuatro hileras de piedras preciosas, / y tu majestad en la diadema de su cabeza.

Además de los reyes o sumos sacerdotes, el resto de los varones, sólo en su boda podían tocarse con diadema, corona o turbante, precisamente porque durante esta celebración se les trata como tales, nombrándoseles con el epíteto de "rey" ${ }^{54}$ o con el nombre de algún monarca especialmente prestigioso: Cantar de los cantares 3, 11 aSalid y contemplad, joh hijas de Sión!, al rey <Salomón> con la corona con que le coronó su madre / el día de sus bodas". Isaías 61, 10 "como un recién casado que lleva el turbante a modo de sacerdoten.

A la corona, acompaña como símbolo de dominio real o sacerdotal, el cetro:

Ester 4, 9 Y habiendo atravesado todas las puertas, se presentó ante el rey. Él estaba sentado en el solio de su realeza, vestido con todo el fausto de su majestad, recubierto de oro y de piedras preciosas. [...] 5, 2 Y resultó que al ver el rey a la reina Ester parada en el patio halló gracia a los ojos del monarca, quien extendió hacia Ester el cetro de oro que él tenía en la mano, [...]

$\mathrm{Ni}$ cetros ni coronas de oro han llegado hasta nuestros días y los únicos ejemplares en metal que conocemos, son de cobre, datados en el calcolítico (segunda mitad del cuarto milenio). Forman parte del Tesoro del Desierto de Judea ${ }^{55}$, escondido en La Cueva del Tesoro, y debieron pertenecer al ajuar de un templo o palacio y ser de uso ceremonial. En este importante depósito aparecieron 429 objetos, entre ellos diez coronas y cinco cetros. La corona más decorada, de forma cilíndrica con los bordes exvasados y un recorte rectangular tiene, además de decoraciones incisas en su superficie, sobre su borde superior y en relieve, dos figuras de pájaros, dos apliques a manera de escaleras rematadas en cuernos de cabra y un curioso ¿estandarte o cetro? Por otra parte el cetro más bello está rematado por cabezas de cabras y carneros. También las cabezas de mazas, aquí depositadas, la mayoría de ellas esféricas, podrían ser remates de cetros. Lo mismo se piensa de una granada de marfil, adquirida por el Museo de Israel, de procedencia desconocida y datada en la octava centuria a.C. que,

${ }_{54}$ El tratar al novio como si fuera un rey nombrándole como tal, aún está plenamente vigente en Marruecos, donde se le denomina sultán.

55 Thomas E. LEVY, "The Chalcolithic Period", Biblical Archaeologist, vol. 49, núm. 2 (Junio 1986), pp. 82-108 y también Bradford D. KelleHER, op. cit., pp. 72-86. 
al parecer, podría ser el único vestigio arqueológico que se puede asociar al templo de Salomón ${ }^{56}$. La función religiosa de los cetros rematados en granadas, aunque desconocida, parece segura, no sólo por las menciones bíblicas al templo de Salomón, sino también por el hallazgo de otros, entre ellos dos de marfil, procedentes del templo cananeo de Lachish y datados en la treceava centuria a.C.

Los parientes, altos funcionarios y servidores reales también son distinguidos con una serie de joyas indicativas. Al hablar de los ídolos ya vimos cómo el cetro también era un distintivo del juez del distrito (Baruk 6,12) A la reina Vastí, el negarse a salir ante el pueblo con la corona real, le costó ser repudiada por su esposo Asuero (Ester 1,11). El monarca tenía extendida esta joya a "otras pertenencias personales" como su caballo (Ester 6,11). Aunque normalmente son collares, hebillas, anillossello y otros tipos de joyas, los símbolos de los personajes vinculados a la realeza:

Génesis 41, 41 Y añadió el Faraón a José: "Mira, te constituyo sobre toda la tierra de Egiptom. 42 Luego se quitó Faraón su anillo de la mano y púsolo en la mano de José, a quien revistió de vestidos de lino y colocó un collar de oro alrededor del cuello.

Daniel 5, 29 Baltasar ordenó inmediatamente que se le pusiera a Daniel un vestido de púrpura y collar de oro al cuello y proclamaron que quedaba constituido el tercero por su autoridad en el reino.

I Macabeos 10, 18 "El rey Alejandro, a su hermano Jonatás, salud. 19 Hemos oído de ti que eres hombre potente y muy digno de ser nuestro amigo. 20 Así, pues, hoy te constituimos sumo sacerdote de tu nación y te damos el título de amigo del rey -y le envió, al propio tiempo un vestido de púrpura y una corona de oro-, para que mires por nuestros intereses y conserves nuestra amistad " [...] 88 Cuando el rey Alejandro oyó estos sucesos concedió nuevos honores a Jonatás, 89 le envió la hebilla de oro, que se acostumbra dar a los parientes de los reyes, y le dio el dominio de Acarón y de todo su territorio.

I Macabeos 11, 57 Antíoco el joven escribió a Jonatás en estos términos: "Yo te confirmo en el sumo sacerdocio, y te constituyo sobre los cuatro territorios, y te concedo ser de los amigos del rey" $58 \mathrm{Y}$ le envió vajilla de oro y un servicio de mesa, otorgándole el derecho de beber en vasos de oro, de vestir púrpura y usar hebilla de oro.

I Macabeos 14, [el rey Antíoco, a Simón Sumo sacerdote y etnarca de los judíos] 43 que tenga cuidado de las cosas sagradas; que sea por todos obedecido; que se inscriban en su nombre todos los documentos públicos del país y que vista púrpura y la fíbula de oro. $44 \mathrm{~A}$ nadie será permitido, ora del pueblo, ora de los sacerdotes, rechazar alguna de estas disposiciones [...] ni vestir púrpura, ni llevar fibula de oro.

56 Nahman AVIGAD, "The Inscribed Pomegranate form the 'House of the Lord'", Biblical Archaeologist, vol. 53, núm. 3 (Septiembre 1990), pp. 157-168. 
En unos textos se menciona la fíbula y en otros la hebilla de oro, aunque no se trata de joyas exclusivas de la élite masculina sino que en otras épocas o de otros metales debían extenderse a la mayoría de la población: Éxodo 35, 22 "Acudieron, pues, los hombres y las mujeres; todos los de corazón generoso aportaron fíbulas, arracadas, anillos, collares y toda suerte de joyas de oro".

Más indicativos de un alto rango eran los collares masculinos, como probablemente era el hallado en la Tumba del Señor de las Cabras ${ }^{57}$, en Ebla, al norte de Siria. Se trata de una banda de oro compuesta de tres secciones con decoración incisa a modo de ancho trenzado. De cada segmento pende un colgante circular con una estrella de seis puntas, entre las que se colocan círculos, todo ello realizado con granulado siguiendo la tradición de la antigua Siria. También, según las menciones contenidas en el Antiguo Testamento, se puede afirmar que el brazalete en el brazo derecho, como el que llevaba el rey Saúl (II Samuel 1,10) debió ser un símbolo de preeminencia social y prestigio: Eclesiástico 21,21 "Como adorno de oro es la instrucción para el prudente,/ y cual brazalete en el brazo derecho".

Pero el tipo de joya masculina mejor documentada por los textos y la arqueología es, sin lugar a dudas, el sello. Símbolo de identificación personal, se empleaba a modo de rúbrica tanto por los reyes, sus altos cargos y parientes como otros personajes que habían alcanzado una cierta preeminencia social y económica. Cuando Tamar, ocultando su personalidad con un velo, se prostituye con su suegro Judá, le pide a cambio, su sello, su cordón y su bastón (Génesis 38,18); gracias a la posesión de estos objetos personales e inconfundibles podrá posteriormente demostrar que se halla encinta de él, salvando así su vida. Con las impresiones en bullas de arcilla fresca se autentificaban decretos o cualquier otro documento escrito en papiros y por ello vimos más arriba cómo el faraón, para conferir poderes a José, le da su anillo-sello. Además se utilizaba también para sellar puertas, arcas o cualquier deposito que no debiera ser abierto sin consentimiento o ante testigos. Así, Gabaelo tenía depositada la deuda contraída con Tobit en unos saquitos con sellos (Tobit 9,5) que abrió y contó en presencia del ángel Rafael, para que quedara constancia que devolvía todo el importe. Para evitar hurtos y saqueos también era frecuente sellar las puertas del templo; Daniel que había llegado a ser confidente del rey Astiages (hoy diríamos "asesor"), se mofa de los manjares que éste ofrece cotidianamente al dios Bel. El monarca, aconsejado por los sacerdotes, para mostrar que es el dios y no ellos quienes consumen

57 Paolo MatThiaE, op. cit, p. 27. 
las ofrendas, después de dejárselas, sella la puerta del templo con su anillo. Los sacerdotes y sus familias entran por otra puerta secreta para coger las comidas y bebidas, pero quedan en evidencia porque Daniel había cubierto el suelo de ceniza y a la mañana siguiente, el rey puede comprobar sus pisadas (Daniel 14). Anteriormente el propio Daniel fue reo custodiado por sellos: Daniel 6, 17 "El monarca dio órdenes en seguida, y llevaron a Daniel y lo arrojaron en la fosa de los leones. [...] 18 Y llevóse una piedra y fue colocada sobre la boca de la fosa, y el rey la selló con su anillo y con el anillo de sus magnates para que no se mudase la suerte de Daniel".

El sello era el símbolo masculino por excelencia de algo precioso y querido:

Eclesiástico 32, 5 Sello de rubí engastado en oro / es un concierto musical en banquete.

6 Sello de esmeralda en engarce de oro / es una melodía de cantos unida a la delicia del vino

Eclesiástico 49, 11 ¿Cómo ensalzaremos a Zorobabel, / a él, que es cual un sello en la mano derecha?

Cantar de los cantares 8, 6 Ponme como sello sobre tu corazón, / cual sello sobre tu brazo; pues fuerte como la muerte es el amor, [...]

Los sellos son el tipo de joya mejor conocida. Por una parte, el número de ellos que ha llegado hasta nuestro días es bastante amplio, ya que, eliminando su engarce de oro, los más extendidos de esteatita, cornalina $\mathrm{u}$ otras piedras semipreciosas, una vez fallecido su propietario pierden su valor y no quedan sujetos a las reutilizaciónes posteriores. Una excepción a esta regla es el frecuente empleo de sellos con nombres y emblemas de reyes, personajes prestigiosos, o dioses, a modo de amuletos, que alarga su vigencia durante tiempos muy posteriores a su supuesta fecha de fabricación, o al periodo del rey o personaje que nombran. Pero este uso no aumenta el valor intrínseco del sello o de la piedra, que no podrá ser reciclada y, finalmente, acaba acompañando los restos de un difunto, o siendo abandonado en antiguos asentamientos. Naturalmente esto no ocurre con los sellos grabados en piedras preciosas como los rubíes o las esmeraldas de los que la ausencia de hallazgos es absoluta, aunque sí se han documentado algunos anillos-sellos de oro. Pero, además de los ejemplares conservados hasta nuestros días contamos con otro método para el estudio de estas joyas que es el hallazgo de sus impresiones en jarras de cerámica o en las bullas de arcilla. Los frecuentes saqueos e incendios de palacios, templos y ciudades provocaban, de forma simultánea, la pérdida de los manuscritos escritos en papiros $u$ otros materiales fungibles y la cocción y por tanto conservación durante dilatadísimos períodos de 
tiempo de las bullas que los sellaban y sus impresiones. La fabricación de sellos era una de las principales ocupaciones de los orfebres y grabadores de piedras ("los lapidarios") existiendo incluso casas o talleres donde se concentraban los artesanos dedicados a esta labor, como la Casa de las Bullas de la ciudad de David, que, al parecer permaneció en uso desde la octava a la sexta centuria a.C., desapareciendo con la destrucción del templo de Salomón y de la ciudad de Jerusalén en el 586 a.C. ${ }^{58}$ Según las formas, inscripciones y motivos iconográficos representados en los procedentes de Palestina, se pueden distinguir varios tipos, trazar su evolución estilística y señalar importaciones, imitaciones e influencias extranjeras.

Uno de los grupos más extendidos son los sellos-escarabeos de origen $\mathrm{O}$ influencia egipcia ${ }^{59}$ que durante la Edad de Bronce cobran una enorme popularidad, difundiéndose por los paises vecinos del Próximo Oriente. Junto con otros productos, testifican las intensas relaciones, unas veces bélicas, otras de alianza o sumisión y casi siempre comerciales, existentes entre los grandes imperios de la antigüedad. El escarabajo es una representación frecuentísima del arte egipcio que simbolizaba el nacimiento, la vida y especialmente la reencarnación en una vida eterna. Alli se le llegaba a considerar un animal sagrado y su representación, el escarabeo, era un poderoso y difundido amuleto tanto o más empleado por los hombres, especialmente soldados, como por las mujeres. Frente a los lujosos ejemplares egipcios de oro y piedras preciosas, la mayoría de los encontrados en la Tierra Prometida son de esteatita, más raramente de cornalina, oro, plata o bronce. La esteatita es un tipo de talco fácil de tallar y grabar, después de lo cual se vidriaba, lo que alteraba su composición química aumentando su dureza y oscureciendo hasta tomar tonos azul oscuro intenso o verde brillante, semejantes al color natural de los escarabajos.

Su periodo de mayor auge, en nuestra zona de estudio es el cananeo y en menor medida, el israelita, siendo posteriormente sustituidos por otros tipos que normalmente descienden en calidad. Los encontrados en la necrópolis de Deir El-Balah ${ }^{60}$ (ver fig. 10.1, 2 y 3), unos perforados para

58 Yigal SHILOH and David TARLER, "Bullae from the City of David: A Hoard of Seal Impressions from the Israelite Period", Biblical Archaeologist, vol. 49, núm. 4 (Diciembre 1986), pp. 196-209.

59 William A. WARD, "Beetles in Stone: The Egyptian scarab", Biblical Archaeologist, vol. 57, núm. 4 (Diciembre 1994).

60 Trude DOTHAN, Excavations at the cementery of Deir El-Balah (Jerusalem: Qedem Monographs of the Institute of Archaeology, The Hebrew University of Jerusalem, 10, Ed. Board, 1979). 

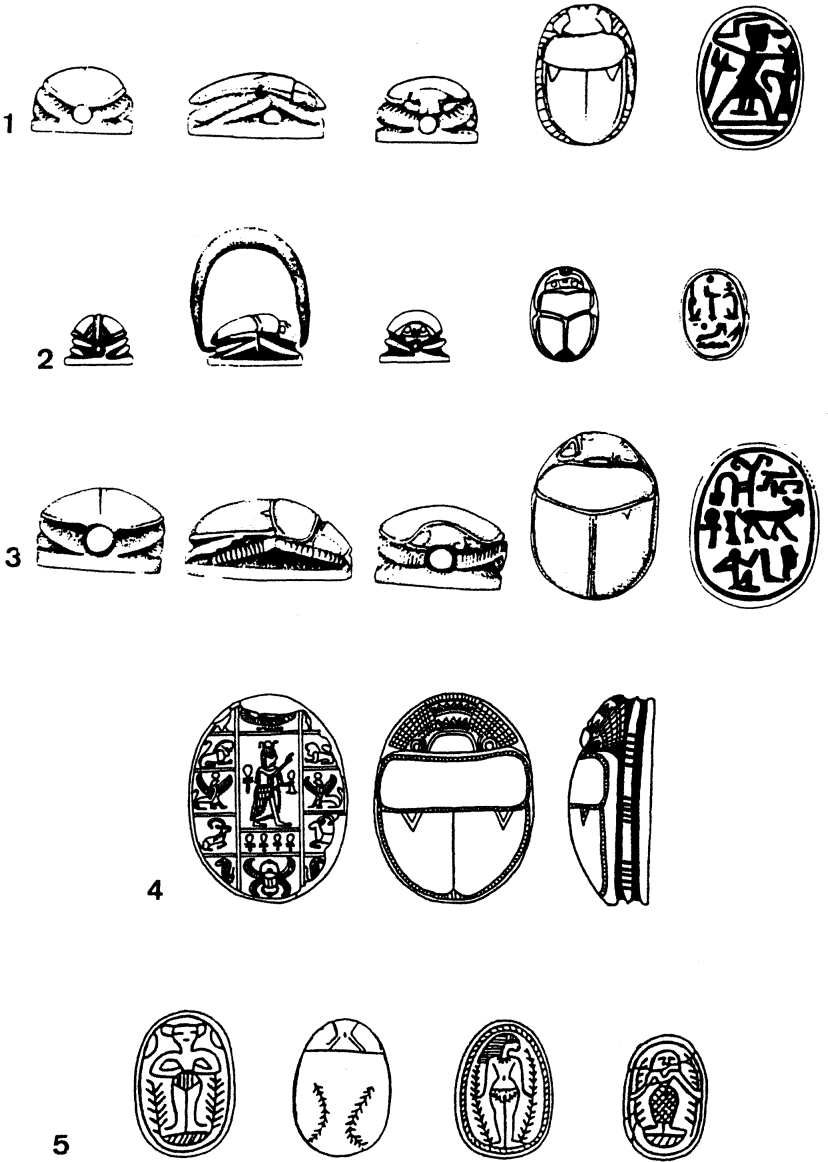

FIG. 10.1.-Escarabeo de esteatita perforada. En la escena se representa un rey egipcio con faldellín y tiara sujetando a una víctima con una mano mientras con la otra blande una cimitarra. La inscripción indica que pertenece al rey. Datado en un periodo no anterior a Ramesses II. 2.Escarabeo de cornalina y plata para el anillo. Se representa al dios Thot coronado con un disco y la leyenda "Señor de Hermópolis". En el otro lado la inscripción "pertenece a Amón" nombre comúnmente dado a Ramesses II. 3.-Escarabeo de esteatita perforado perteneciente a un oficial egipcio que según la tipología de la inscripción debió pertenecer a la XII dinastía. Por su hechura se puede discernir que fue realizado en Canaán por un artista local, no antes de la VIII dinastía (imitación tardía cananea) y por tanto no tuvo porqué pertenecer a un oficial egipcio, ni resulta indicativo de la administración egipcia del área. 1, 2 y 3.Recuperados en las tumbas de Deir El-Balah (Bronce final aproximadamente treceava centuria a.C.) según Trude Dothan, 1979. 4.-Escarabeo de tradición fenicia. El dorso está mucho más decorado que lo que acostumbraban los egipcios. La base es una mezcla de tradiciones: La figura central lleva un tocado egipcio y un traje cananeo; Los animales alados con disco solar están tomados del arte asirio y el escarabajo con cuatro alas es una adaptación cananea de un motivo egipcio probablemente por influencia de los prototipos hurritas. Tomado de William A. WARD, "Beetles in Stone: The Egyptian Scarab", Biblical Archaeologist, vol. 57, núm. 4 (Diciembre 1994). 5.-Escarabeos con representaciones de la diosa desnuda, Astarté, en pose típicamente cananea y no egipcia. Tomado de William A. WARD, "Beetles in Stone: The Egyptian Scarab", Biblical Archaeologist, vol. 57, núm. 4 (Diciembre 1994). 
su suspensión en collares o gargantillas y otros preparados para su engarce en anillos son bastante fieles a los modelos egipcios en sus motivos e inscripciones, con representación de faraones o deidades propias, distinguiéndose los de fabricación local, de los importados por su peor factura y porque normalmente citan a faraones de tres y hasta cinco siglos anteriores a la cronología del yacimiento, lo que indica su uso como amuletos más que como sellos. Esto será una norma también con sellos de otros tipos y épocas, aunque no siempre impide o elimina su función original. Además se han encontrado algunos que tan sólo tienen grabadas algunas líneas, semejantes a las del anillo de la figura 11.2, que sin duda serían marcas de identificación personal. El sello fenicio de la figura 10.4 es un ejemplo emblemático del sincretismo y difusión de los escarabeos. Tiene un labrado del dorso mucho mas rico y recargado de lo habitual en los ejemplares egipcios y una abigarrada mezcla de motivos, egipcios, cananeos, sirios, mesopotámicos y babilónicos, representados en su parte plana, que parece avalar su función de joya-amuleto. Por último, los tres escarabeos con la imagen de la diosa desnuda (Astarté) son por su factura y motivo, marcadamente cananeos, con representaciones frontales de la diosa que nunca se hubieran realizado en Egipto y de bastante tosca factura. El culto a esta diosa era mayoritariamente femenino lo que señala el sexo de sus propietarias, además de volver a incidir en su carácter como amuletos o talismanes.

Todavía mas primitivos, los sellos de tradición o importación mesopotámica son cilíndricos y están perforados longitudinalmente para su suspensión por medio de un cordón (probablemente de este tipo es el que Tamar pidió a Judá). Se hacían rodar sobre la arcilla fresca para su impresión (ver fig. 11.5) consistente en representaciones características de Mesopotamia, Babilonia y Siria, como la omega, símbolo de Astarté, la diosa desnuda u otras deidades; mitos y ritos sumerios; grifos, animales alados, el creciente lunar, la estrella de seis puntas, etc. Tanto en este como en el resto de los modelos de sello, cuando llevan inscripciones están grabadas al revés para que puedan leerse correctamente en la impresión. Mucho menos frecuente es el sello rectangular representado en la figura 11,6 que, al parecer estaba engarzado en un anillo. Aunque el tipo de sello-anillo mejor documentado de forma oval o rectangular era de un sólo material con su parte superior ensanchada y aplanada para contener la inscripción o el motivo del sello, tal como los reproducidos en la figura, 11.1 y 2 . La ausencia de anillos en la indumentaria cotidiana del israelita medio ha quedado reflejada en un texto que, a la vez, nos informa cómo otras tribus próximas sí los llevaban: 


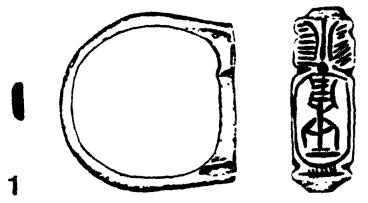

2
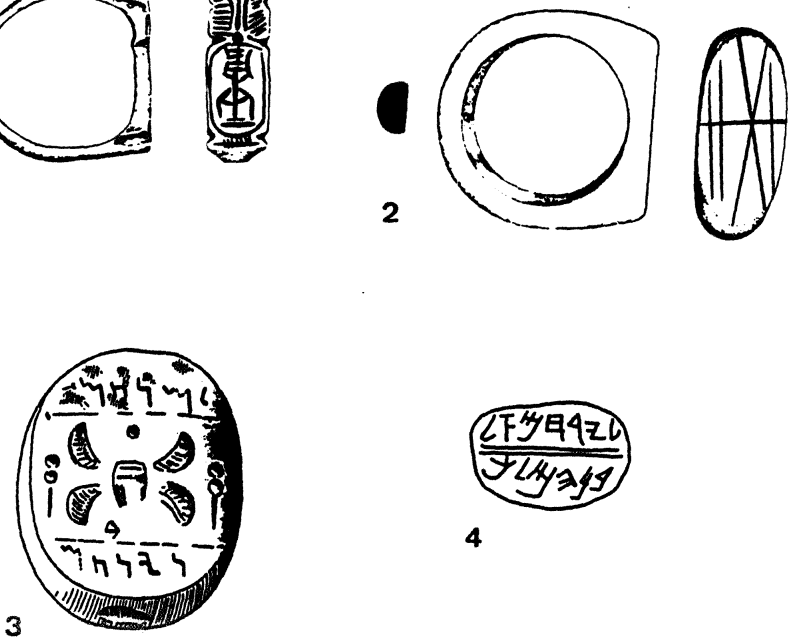

4

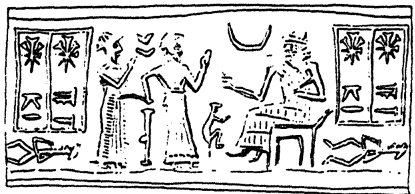

5

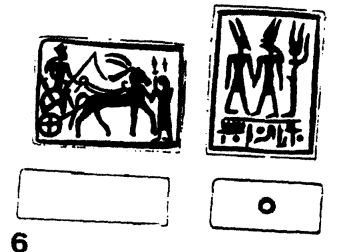

FIG. 11.1.Anillo-sello de oro; en el cartucho aparece la figura del dios Bes con disco solar y plumas, datado entre la XXVIII y la XXIX dinastías. 2.Anillo de cornalina, en el cartucho sólo tiene unas líneas incisas, similares a las de algunos escarabeos que debían ser un símbolo de identificación personal común el Canaán de la XIX dinastía. 3.-Sello ammonita de forma oval, perteneciente a un tal Mena-

hem. En el centro se ve un escarabajo con cuatro alas y un disco solar encima flanqueado por dos ¿árboles o plantas? Tomado de Randall W. YounKER, "Israel, Judah. and Ammón and the Motifs on the Baalis Seal from Tell el-'Umeirin, Biblical Archaeologist, vol. 48, núm. 3 (Septiembre 1985), pp. 173-180. 4.-Impresión de un sello en una bulla. La inscripción dice: "pertenece a Jerahmeel / el hijo del rey", tomado de Nahaman AvigaD, "Baruch the Scribe and Jerahemeel the King's Son", Biblical Archaeologist, vol. 42, núm. 2 (Primavera 1979). 5.-Impresión de un sello cilíndrico tomado de Elizabeth C. STONE and Paul ZIMANSKI, "Mashkan-shapir and the anatomy of an Old Babylonian City", Biblical Archaeologist, vol. 55, núm. 4 (Diciembre 1992). 6.- Sello de cornalina perforado de forma cuadrangular y con restos visibles del anillo. En una cara representa tres dioses: el dios Min en forma humana llevando tocado de doble pluma, el dios Horus en forma humana con cabeza de falcón llevando la doble corona de Egipto y el dios Amón en forma humana llevando tocado de doble pluma. En la otra cara se ve un rey egipcio de pie sobre un carro, en una mano lleva el cetro y las riendas y en la otra un látigo. el caballo está tocado con dos plumas, en frente, de pie, un sirviente. 1, 2 y 6.-Recuperados en la necrópolis de Deir El-Balah (Bronce final aproximadamente treceava centuria a.C.) según Trude DOTHAN, 1979. 
Jueces 8, $24 \mathrm{Y}$ añadióles Gedeón:

-Un favor os pido: déme cada uno los anillos de su botín.

Pues [los enemigos] llevaban anillos de oro porque eran ismaelitas [...] 26 Y resultó el peso de los anillos de oro que él pidiera mil setecientos siclos de oro, aparte de las medias lunas, las cadenillas de perlas y los vestidos de púrpura que llevaban los reyes de Madian, además de los collares que sus camellos traían al cuello.

En el periodo de los reyes (Edad del Hierro antes de la destrucción del templo de Salomón) se extienden por Palestina los sellos ovales con el dorso convexo, suelen estar divididos en dos partes marcadas por líneas, colocándose en la superior el epígrafe "para Fulano" (perteneciente a Fulano) y en la inferior "hijo de Zutano", o "que está sobre la casa" (gobernador de un rey). Especial interés en la comunidad judía despiertan los que llevan nombres de individuos que se pueden encontrar citados en el Antiguo Testamento, como la impresión representada en la figura $11.4^{61}$. Otras veces los de este tipo, claramente fabricados como sellos más que como amuletos llevan en su centro o en alguna de las dos partes en que se dividen, representaciones iconográficas como el león, el gallo, o el escarabajo de cuatro alas. Este último motivo de origen egipcio pero que llegó a los israelitas a través de los amonaitas en el siglo IX a.C. ${ }^{62}$, vuelve a incidir en el carácter mágico y los poderes atribuidos a los escarabajos y sus representaciones.

A la función social de las joyas masculinas, aunque sólo sea de pasada hay que añadir la mención a determinadas piezas de la indumentaria que cumplían los mismos fines de indicar y elevar el prestigio de sus portadores, como las túnicas o cualquier otra prenda que fuera de lino teñido de color púrpura y el nombradísimo ceñidor, donde se llevaban objetos de valor, como amuletos protectores, puñales y otras pequeñas armas, etc. y que en sí mismo parecía, si no tener propiedades mágicas, resultar altamente carismático y preciado, aunque no sería correcto equipararlo a un cinturón o pensar que podría ser metálico guarnecido de piedras.

Las armas de plata u oro también son un elemento de prestigio social y por ello se regalaban a los monarcas como ofrenda, también los ángeles suelen emplear, espadas y otros instrumentos de metales nobles. El siguiente relato, parece extender este tipo de orfebrería al común de los

61 Nahaman AVIGAD, "Baruch the Scribe and Jerahemeel the King's Son", Biblical Archaeologist, vol. 42, núm. 2 (Primavera 1979).

62 Randall W. YOuNKER, aIsrael, Judah, and Ammón and the Motifs on the Baalis Seal from Tell el-'Umeiri,, Biblical Archaeologist, vol. 48, núm. 3 (Septiembre 1985), pp. 173-180. 
soldados de determinados ejércitos, aunque tal vez los portaran como presente para David: 1 Crónicas 18, 3 "Asimismo David batió a Hadadézer, rey de Sobá, en Jamat, cuando éste partió a restablecer su dominio sobre el río Eufrates. [...] 7 Y se apoderó David de los escudos de oro que traían los súbditos de Hadadézer y los trajo a Jerusalén".

Además a las joyas e indumentaria masculina hay que unir como indicativo de la preeminencia social, la rica orfebrería acumulada por monarcas y altos cargos, que muestran ostentosos ante sus súbditos o invitados. Así, Ezequías que tenía una casa con sus tesoros, no dudó en enseñarla a los embajadores del rey de Babilonia ${ }^{63}$ :

2 Reyes 20, 12 En aquel tiempo, Merodak Baladán, hijo de Baladán, rey de Babilonia, envió cartas y un presente a Ezequías, pues tuvo noticia de que había estado enfermo. 13 Ezequías se alegró con los embajadores y les mostró toda su casa de los tesoros, la plata, el oro, los aromas, el aceite más exquisito, su armería y cuanto se hallaba en sus tesoros. No hubo cosa que no les mostrara, así en su casa como en todo su dominio. 14 Entonces vino el profeta Isaías al rey Ezequías y dijole: [...] 17 Mira; van a llegar días en que se llevará a Babilonia cuanto hay en tu casa y lo que atesoraron tus padres hasta el día presente...

Aunque, si exceptuamos el relato sobre el reinado de Salomón, que merecerá un apartado independiente y que naturalmente tenía todo los vasos de beber de oro (2 Crónicas 9,15-20), es en el libro de Ester donde, con lograda teatralidad, mejor se recoge la organización y riquezas de la corte de un rey, en este caso extranjero:

Ester 1, 4 Desplegó así la brillante riqueza de su reino y el esplendor relumbrante de su dignidad durante muchos días, ciento ochenta días. 5 Transcurrido este plazo, el rey dio a todos los habitantes de Susa, la ciudadela, del grande al chico, un convite por espacio de siete días en el patio del jardín del palacio real. 6 Colgaduras de lino blancas y de color violeta pendían sujetas por cordones de seda marina y púrpura roja a anillas de plata y columnas de mármol, divanes de oro y plata descansaban sobre un pavimento de piedra esmeraldina, mármol, alabastro y enlosado precioso. 7 Las bebidas servíanse en vasos de oro y vasos de variadas formas, y abundante vino regio, con regia liberalidad.

De las vajillas de oro o plata, los vasos (copas y cuencos), son las únicas piezas de las que ha llegado algún ejemplar hasta nuestros días ${ }^{64}$.

63 El relato se repite de forma casi idéntica en Isaías 39, 1 y 2.

64 Es en el periodo persa cuando proliferan los cuencos y tazones de plata, como los descubiertos en Guézer y Sharuhen (Tell el-Far'ash) al sur de Palestina con la característica decoración agallonada, ver G. Ernest WRIGHT, op. cit., p. 300. También una bello tritón de oro de estilo persa, unido en su base al torso de un león y da- 
Otros relatos sobre el ajuar de templos y palacios confirman su extendido uso por la clase dominante. Mas arriba vimos que Antíoco el joven envió a Jonatás, una vajilla de oro y un servicio de mesa (Macabeos 11,58) al concederle el título de "amigo del rey" y, al tratar algunos ejemplos de magia, cómo José empleaba para beber la misma copa de plata con que realizaba sus augurios. También de otros reyes, especialmente extranjeros, se nos cuenta que se complacían en poseer y utilizar vajillas y otros objetos o muebles de oro:

Judit 10, 21 Estaba Holofernes descansando sobre su lecho protegido por el conopeo, que estaba entretejido de púrpura y oro, esmeraldas y piedras preciosas. 22 Anunciáronsela, y salió al vestíbulo. Lámparas de plata le precedían [...] 15, 11 [...] Y dieron a Judit el pabellón de Holofernes y todos sus objetos de plata, los lechos, la vajilla y todo su ajuar.

1 Reyes 10, 21 Todos los vasos en que bebía el rey Salomón eran de oro purísimo, y toda la vajilla de la Casa del bosque del Líbano era de oro finísimo.

Daniel 5, 2 Bajo el influjo del vino, Baltasar ordenó traer los vasos de oro y plata que su antepasado Nabucodonosor había sacado del templo de Jerusalén, para que bebieran en ellos el rey su sus magnates, sus esposas y sus concubinas.

$\mathrm{Si}$, como ya hemos mencionado, durante la celebración de la boda, los novios son tratados como reyes comprenderemos que el pabellón nupcial también se asemejara en sus riquezas, a las dependencias de éstos: Cantar de los cantares 3, 9 "Un pabellón nupcial hízose el rey / $<$ Salomón> de las maderas del Libano. 10 Sus columnas ha hecho de plata, / su respaldo de oro, su silla <tapizada> de púrpura, / su interior taraceado con amor por las hijas de Jerusalén".

\section{JOYERÍA Y ORFEBRERÍA EN OFRENDAS, TRIBUTOS, SAQUEOS Y BOTINES}

Sin duda el establecimiento de relaciones comerciales era el método más cómodo para aumentar el volumen de metales nobles y piedras preciosas de naciones y monarcas pero, si seguimos los relatos bíblicos veremos que la acumulación de estas riquezas se nutría tanto o más de otras

tado en la quinta centuria a.C., se encuentra en el Museo Metropolitano de Nueva York, ver Carey A. MOORE, "Archaeology and the Book of Esther", Biblical Archaeologist, vol. 38, núms. 3 y 4 (Septiembre-Diciembre 1975), pp. 62-78. De un periodo anterior, periodo israelita, inicios de la Edad del Hierro, contamos con un servicio para vino labrado en bronce y depositado en la Tumba de la reina. Ver James B. PIRCHARD, "The First Excavations at Tell es-Sa' idiyeh", Biblical Archaeologist, vol. XXVIII, núm. 1 (Febrero 1965), pp. 10-17. 
fuentes alternativas. En primer lugar hay que mencionar los regalos y ofrendas voluntarias que junto a los tributos obligatorios en forma de joyas o piezas de orfebrería materializaban las relaciones de alianza, dominio y sumisión:

2 Crónicas 9, 1 Habiendo tenido noticia la reina de Saba de la fama de Salomón, vino a Jerusalén [...] acompañada de numerosísimo séquito, de camellos cargados de aroma, oro en gran cantidad y piedras preciosas y llegó donde Salomón [...] 9 Después regaló ella al rey ciento veinte talentos de oro, aromas en grandísima cantidad y piedras preciosas [...] 14 también todos los reyes de Arabia y los gobernadores del país traían oro y plata a Salomón.

10, 23 Excedió, pues, el rey Salomón a todos los reyes de la tierra en riqueza y sabiduría. 24 Todo el mundo trataba de ver a Salomón, para oir la sabiduría que Dios había puesto en su corazón. 25 Y cada uno le traía todos los años su presente, objetos de plata y objetos de oro, vestidos, armas, aromas, caballos y mulos.

Sin duda Salomón era quien mayores riquezas atesoró gracias a las ofrendas y tributos, pero no es el único caso y en tiempos muy posteriores se mantenía el método, empleando incluso para ello, los bienes del templo:

2 Reyes 12, 17 [...] Jazael, rey de Siria [...] se dispuso a subir contra Jerusalén. 18 Más Joás, rey de Judá, tomó todas las cosas sagradas que Josafat, Joram y Ocozías, antepasados suyos, reyes de Judá, habían dedicado, lo que él mismo había ofrecido y todo el oro que se hallaba en los tesoros del templo de Yahveh y del palacio real, y lo envió a Jazael, rey de Siria, el cual se retiró de Jerusalén.

2 Reyes 16, 7 Ajaz, entonces, envió embajadores a Tiglat-Piléser, rey de los asirios, diciendo: "Soy tu servidor y tu hijo, sube y sálvame de la mano del rey de Siria y de la mano del monarca de Israel que se han levantado contra mí. 8 Y Ajaz tomó el oro y la plata que se encontraba en el templo de Yahveh y en los tesoros del palacio real, y lo mandó como presente al rey de los asirios. 9 El monarca de Asiria le atendió y subió contra Damasco, se apoderó de ella [...]

I Macabeos 10, 28 Os perdonaremos muchas deudas y os haremos regalos. 29 Ya desde ahora yo os descargo y perdono a todos los judíos los tributos y el impuesto de la sal y de las coronas ${ }^{65}$.

I Macabeos 14, 24 Después de estos sucesos envió Simón a Numenio a Roma con un escudo grande de oro de mil minas de peso para renovar la alianza con ellos.

Pero cuando las relaciones entre unos y otros pueblos eran belicosas, no se interrumpe la circulación de los metales nobles y, gracias al botín, también se acopian riquezas y tesoros:

65 Nota del traductor: «Las coronas: era un impuesto pesado que había venido a reemplazar los dones espontáneos ofrecidos al soberano. Se enviaba a veces a los reyes una corona de oro con ocasión de una victoria o de algún fausto acontecimiento". 
Nabum 2, 9-10 [Asalto de Nínive] ¡Saquead la plata, saquead el oro! El ajuar no tiene fin, una fortuna en toda suerte de objetos preciosos.

1 Reyes 20, 1 Ben-Hadad, rey de Siria, juntó todo su ejército [...] puso sitio a Samaria y la atacó. 2 Y envió emisarios a Ajab, rey de Israel, a la ciudad, 3 y díjole: [...] 5 [...] Tu plata, tu oro, tus mujeres y tus hijos me has de entregar; 6 de cierto mañana a estas horas enviaré a ti mis súbditos, que registrarán tu casa y las casas de tus súbditos y echarán mano de cuanto haya más precioso a sus ojos y se lo llevarán.

Los inmensos tesoros y riquezas depositados en el mítico primer templo de Jerusalén, construido por Salomón, también estuvieron sujetos a los robos, saqueos y expolios, siendo abundantes los relatos sobre profanaciones y hurtos ${ }^{66}$ :

1 Reyes 14, 25 Y sucedió que, el año quinto del rey Roboam, Sisaq, monarca de Egipto, subió contra Jerusalén. 26 Y se apoderó de los tesoros de la casa de Yahveh [...] robando asimismo todos los escudos de oro que Salomón había fabricado. 2 Reyes 14, 13 y Joás, rey de Israel, hizo prisionero a Amasías, rey de Judá, [...] después se lo llevo a Jerusalén y abrió en la muralla de la ciudad una brecha de cuatrocientos codos [...] 14 y se apoderó de todo el oro y la plata y de cuantos objetos se hallaban en el templo de Yahveh y en los tesoros del palacio real, y asimismo de rehenes, y luego se volvió a Samaria.

2 Reyes 24, 11 Y Nabucodonosor, rey de Babilonia, llegó contra la ciudad, mientras sus servidores la asediaban [...] 13 Y, como Yahveh había indicado, sacó de allí todos los tesoros del templo del Señor y los del palacio real e hizo pedazos todos los objetos de oro que había fabricado Salomón, rey de Israel, para el templo de Yahveh.

I Macabeos 1, 23 Entró con insolencia en el santuario, tomó el altar de oro, el candelabro de la luz con todos sus utensilios, la mesa de los panes de la proposición, las tazas, las copas, los incensarios de oro, la cortina, las coronas, y arrancó todo el decorado de oro que cubría la fachada del templo. 24 Tomó asimismo la plata, oro y vasos preciosos, y se llevó los tesoros escondidos que pudo hallar.

En más de una ocasión Dios no queda impasible ante estos actos y manda castigos o ángeles armados que los impidan:

II Macabeos 3, 25 Porque se les apareció un caballo montado por un jinete terrible, adornado de riquísimo caparazón; lanzándose impetuosamente a Heliodoro [que iba a saquear los tesoros del templo], le acoceó con las patas delanteras. El que lo montaba parecía tener armadura de oro.

II Macabeos 5, 1 Por este tiempo organizó Antíoco su segunda expedición contra Egipto 2 y sucedió que, por espacio de casi cuarenta días, por toda la ciudad aparecieron en el aire jinetes corriendo con túnicas doradas, armados de lanzas, a semejanza de cohortes, 3 y escuadrones de caballos, alineados en orden de bata-

66 Otras menciones no reproducidas ni en este ni en otros apartados pueden leerse en Baruk 1,8 y 2 Reyes 25,8-9. 
lla, ataques y cargas de una y otra parte, agitación de escudos, multitud de lanzas, espadas desenvainadas, lanzamiento de dardos, resplandores de armaduras de oro y corazas de todas clases [...] 15 No contento con esto, se atrevió a entrar en el templo más santo de todo el universo [...] 16 Tomando con sus manchadas manos los vasos sagrados y arrebatando las ofrendas entregadas por muchos reyes para aumentar la gloria y dignidad del lugar, las entregaba a manos profanas.

Dios había instituido una casta sacerdotal que se preocupara del culto, del mantenimiento del templo y naturalmente del acopio y administración de sus tesoros. Se trata de una selecta élite, los levitas, descendientes del primer sumo sacerdote Aarón, hermano de Moisés, con reglas y prescripciones de pureza más estrictas que las del resto del pueblo judío. Pero entre ellos también se dieron casos de hurtos y corrupción semejantes a los que al hablar de los ídolos se relataban en la epístola de Jeremías:

2 Reyes 12, 13 Pero del dinero ingresado en el templo de Yahveh no se hacía en éste ni jofainas de plata, ni cuchillos, aspersorios, trompetas ni ningún otro objeto de oro o plata; 14 pues se daba a quienes hacían las obras, y reparaban con él el templo de Yahveh. 15 Y no se exigían cuentas a los hombres en cuyas manos se entregaba el dinero para darlo a los que hacían las obras, porque obraban de buena fe. $16 \mathrm{El}$ dinero del sacrificio por la culpa como el dinero por el sacrificio por el pecado no ingresaba en el templo de Yahveh; era para los sacerdotes.

\section{DIOS AMANTE DEL ORO Y LAS PIEDRAS PRECIOSAS}

La ausencia prácticamente absoluta de imágenes de Yahveh en los yacimientos, que tan bien se ajusta a los preceptos bíblicos, no significa en absoluto que Dios no sea un ferviente amante del oro y las piedras preciosas de cuya obtención, elaboración y utilización con fines religiosos se ocupará personalmente, al mismo tiempo que trata de impedir que estos preciados bienes se desvien a otros usos.

Nada más iniciarse el Génesis, encontramos ya una significativa mención:

Génesis 2, 8 Luego Yahveh Dios plantó un vergel en Edén, al oriente, para colocar allí al hombre que había formado [...] 10 Brotaba de Edén un río para regar el vergel, y desde allí dividíase y formaba cuatro brazos. $11 \mathrm{El}$ nombre de uno es Pisón, el cual circuye todo el país de Javilá, donde está el oro. $12 \mathrm{El}$ oro de aquel país es excelente, dándose también allí el bedelio y la piedra de sóham.

Yahveh coloca al hombre en un lugar "paradisíaco" - nunca mejor dicho-, en el cual, por supuesto existían yacimientos de oro y piedras preciosas. Es significativo que del Pisón, uno de los dos ríos imaginarios, 
ya que los otros se identifican con el Tigris y el Éufrates es del único que se cita las riquezas contenidas en su cuenca. En una descripción posterior, dirigida al príncipe de Tiro, las ricas materias primas han aumentado alcanzando una dimensión mítica:

Ezequiel 28, 13 en el Edén, huerto de Dios, habitabas; / toda suerte de piedras preciosas eran tu vestido: sardónices, topacios y jaspes, /crisólitos, ónices y berilos, zafiros, carbunclos y esmeraldas / y oro obra de tu hermosura; y tus minas fueron establecidas cuando fuiste creado.

También será el propio Dios quien se preocupe de proporcionar joyas al pueblo hebreo en su huida de Egipto, ya que allí, por el estado de esclavitud en que había caído, no es probable que poseyeran muchos de estos bienes. Hasta tres menciones casi idénticas, contiene el Exodo sobre este asunto $(3,21-22 ; 11,1-2$ y $12,35-36)$ de las que sólo reproducimos la primera

Éxodo 3, 19 Ya sé que el rey de Egipto no os dejará partir sino mediante una mano fuerte. 20 Pero extenderé mi mano y heriré a Egipto con toda suerte de prodigios que obraré en medio de él, y después os dejará salir. 21 Además, yo haré que halle gracia este pueblo a los ojos de los egipcios, y sucederá que, cuando partáis, no marcharéis de vacío, 22 pues cada mujer pedirá a su vecina y a la huéspeda objetos de plata, de oro y vestidos, que pondréis a vuestros hijos y vuestras hijas, despojando así a los egipcios.

Según la nota introducida, en la edición que manejamos (p. 96), Coppens interpreta que Dios quiso que el pueblo escogido saliera de Egipto "como se deja partir a una novia", colmado de dones de oro y plata. Sin embargo, nos parece más importante que estos textos recojan e intenten explicar una de las principales características de la joyería del periodo Cananeo (Edad del Bronce, antes de la conquista de la Tierra Prometida), su fortísima relación con las producciones egipcias, siendo como hemos visto, muchos de los objetos hallados, importaciones o imitaciones de estas manufacturas.

El acopio de joyas destinadas al culto, en todas sus manifestaciones: arquitectónicas, mobiliarias, de ajuar e indumentaria está prescrito por el propio Dios, que escoge este tipo de ornamentación en una de sus apariciones: Éxodo 24,9 "Luego Moisés subió con Aarón, Nadab, Abihú y setenta de los ancianos de Israel, 10 y contemplaron al Dios de Israel: bajo sus pies había como un pavimento de baldosas de zafiro y semejante en claridad al mismo cielo".

Si otras divinidades, los reyes o los personajes de elevado rango acumulan en sus templos y palacios enormes tesoros, Yahveh no se queda a 
la zaga, utilizando además los mismos métodos: impuestos, ofrendas voluntarias y botines de guerra. El acopio de riquezas por Yahveh tiene su inicio en el Éxodo, donde, al realizarse el censo ${ }^{67}$, se debe presentar un tributo a Yahveh (Éxodo 30,11-15) como rescate por la propia persona (para expiar los pecados cometidos durante la estancia en el desierto) consistente en medio siclo, según el siclo del santuario que era de un peso superior al normal. También antes de la conquista de la Tierra Prometida, se acumulan joyas por mandato divino para erigir un santuario con todos sus muebles y objetos destinados al culto: El tabernáculo estaba compuesto por diez tapices (Éxodo, 26), enlazados con cincuenta corchetes de oro situados en el atrio, que tenía hasta 70 columnas de bronce, todas ellas con escarpines y anillos de plata (Éxodo 27,9-19) En su interior se depositaron: Un altar de madera de acacia recubierto de bronce (Éxodo 27,1-8) con todos sus accesorios de este metal (paletas, aspersorios, trinchantes y braseros), otro altar donde quemar incienso, con dos cuernos en su superficie, todo él de acacia recubierta de oro, al igual que los varales para su transporte con anillas, molduras, y otras piezas de oro (Éxodo 31). El arca de los mandamientos (Éxodo 25) de madera de acacia revestida de oro, con su tapa, el propiciatorio, de oro puro, al igual que los dos querubines ${ }^{68}$ posados sobre ella; un mesa también áurea y la vajilla, fuentes y copas, del mismo metal (Éxodo 25,29-36); una pila de bronce para las abluciones (Éxodo 31,18): un candelabro de seis brazos, hecho en oro puro y trabajado a cincel (Éxodo 38,17-25); siete lámparas con sus despabiladeras y sus platillos portapabilos de oro puro (Éxodo 25,37). Las instrucciones que Yahveh da sobre como deben ser muebles e inmuebles se detallan rigurosamente, con dimensiones y formas, de manera que más de una vez se ha intentado su representación basándose en ellas. También es el mismo Dios quien se preocupa de seleccionar e inspirar a los artífices que elaborarán todas las obras ${ }^{69}$ :

Éxodo 35, 30 Luego Moisés dijo a los hijos de Israel: «Mirad, Yahveh ha llamado nominalmente a Besalel, hijo de Urí, hijo de Jur, de la tribu de Judá, 31 y lo ha

67 En el censo sólo constaban los varones mayores de veinte años.

68 Los querubines, de los que el historiador judío Josefo dijo en el siglo I d.C. que no se podía saber realmente lo que eran, y que posteriormente se interpretaron como la segunda escala de la primera jerarquía de los ángeles, hoy se sabe con certeza que se trataba de esfinges aladas. Este tipo de representación era frecuentemente vehículo en que se transportaba o asentaba un dios o un rey en el arte palestino y sirio, (en éste y otros casos, una deidad invisible). Ver G. Ernest WRIGHT, op. cit., pp. 202-203.

69 También en Éxodo 31,1-11. 
llenado de espíritu divino, en sabiduría e inteligencia, ciencia y pericia para toda clase de trabajo; 32 para planear obras de arte, para labrar el oro, la plata y el bronce, 33 para tallar piedras de engastar [...] 34 También ha dotado su corazón del don de la enseñanza: tanto a él como a Oholiab, hijo de Ajisamak, de la tribu de Dan.

Otras piezas de orfebrería fabricadas por mandato divino son dos trompetas de plata, labradas a martillo, empleadas para convocar a la comunidad y dar la señal de mover el campamento (Números 10,1).

Mención independiente merece la indumentaria sacerdotal, también dictada por Dios, que nos parece más indicado tratar aquí, que en el ámbito de la joyería masculina por formar parte de los objetos destinados al culto y por tanto pertenecientes a la divinidad. Las prendas descritas (Éxodo 28 y 39) son el efod, el manto, la túnica de tejido de punto, la tiara y el cinturón. El efod era una vestidura sagrada sin mangas que, sobre las demás, se ponían los sacerdotes. Se trata de un elemento de culto tomado de los cananeos, considerado en si mismo un ídolo (su empleo como tal, lo vimos al tratar de éstos, cuando Miká se fabrica un ídolo de fundición, un terafim y un efod, Jueces 17,4) o, como en el caso de Yahveh, el símbolo visible de una deidad invisible ${ }^{70}$ :

Éxodo 28, 6 Harán el efod de oro, púrpura violeta, púrpura escarlata, carmesí y lino fino de hilo torzal [...] ${ }^{71} 7$ Llevará unidas dos hombreras a sus extremos [...] 8 El cíngulo que rodeará a aquél por encima será de la misma labor que él [...] 9 Y tomarás dos piedras de ónice, sobre las cuales grabarás los nombres de los hijos de Israel, [...] 11 [...] como lo hace un lapidario al grabar un sello; engastadas en filigranas de oro las harás. 12 Después colocarás las dos piedras sobre las hombreras del efod, cual piedras de recuerdo para los hijos de Israel [...]

13 Harás también filigranas de oro, 14 y dos cadenillas de oro puro, que harás a manera de cordones, labor de trenzado; luego fijarás las cadenillas así trenzadas sobre las filigranas.

Sobre el efod se coloca el pectoral o racional, de los mismos tejidos que éste, pero todavía más cargado de oro y piedras preciosas:

Éxodo 28, 17 Lo guarnecerás de una guarnición de pedrería con cuatro filas de piedras. En la primera fila, una cornalina, un topacio y una esmeralda; 18 en la segunda fila, un rubí, un zafiro y un jaspe; 19 y en la tercera fila, un ópalo, una ágata y una amatista; 20 en la cuarta fila, un crisolito, un sóbam y un ónice. Irán

70 William Foxwell AlBright, op. cit., p. 201.

71 En Éxodo 39,3 se añade: aLaminaron los lingotes de oro y los cortaron en filamentos para entretejerlo en el tejido de púrpura violeta, en el de púrpura escarlata, en el de carmesí y en el de lino fino, resultando una labor artística». 
engastadas en oro en sus monturas. 21 Las piedras corresponderán a los nombres de los hijos de Israel: doce [.....] estarán grabadas como sellos, cada una con su nombre con arreglo a las doce tribus.

22 Fabricarás también sobre el pectoral cadenetas de oro puro, trenzadas a manera de cordón. 23 También harás sobre el pectoral dos anillos de oro, y pondrás los dos anillos a los dos extremos del pectoral. 24 Meterás los dos cordones de oro por los dos anillos a los extremos del pectoral; 25 ligarás los otros dos cabos de los dos cordones a las dos monturas, y fíjalos así en las hombreras del efod por su parte delantera [...] $28 \mathrm{El}$ pectoral se unirá por su anillos a los anillos del efod mediante un cordón de púrpura violeta, de suerte que quede el pectoral encima del cíngulo del efod [...]

Del manto cabe destacar:

Éxodo 28, 33 En su ruedo inferior pondrás granadas de púrpura violeta, púrpura escarlata y carmesí, todo en torno de sus bordes y alternando con ellas campanillas de oro alrededor [...] 35 Aarón lo llevará al oficiar, para que se oiga el tintineo cuando él entre en el santuario ante Yahveh y cuando salga, y así no muera.

Frazer ${ }^{72}$ aclara que, con el tintinear de las campanillas se pretendía ahuyentar a los demonios que acechaban a la puerta del santuario, si Aarón, o cualquier otro sacerdote, los hubiera introducido con él, Dios le habría castigado con la muerte. Aunque el texto sólo menciona la necesidad del tintineo para evitar la muerte, sin explicar el porqué de ésta. Otra joya que el sacerdote llevaba sobre la parte delantera de la tiara, es una lámina de oro a modo de diadema con el grabado: "Consagrado a Yahveh". Por último, se explica cómo las vestiduras de Aarón serán heredadas por sus hijos que también heredarán el cargo de sacerdote.

Para acopiar los bienes destinados al tabernáculo y los objetos de culto que hemos mencionado cada uno de los doce jefes de las tribus de Israel dio una ofrenda:

Números 7, 84 Esto es lo que fue ofrecido por los príncipes de Israel en la consagración del altar el día que fue ungido: doce fuentes de plata, doce copas argénteas, doce incensarios de oro. 85 Cada fuente de plata pesaba ciento treinta siclos y cada copa, setenta, siendo toda la plata de estos utensilios dos mil cuatrocientos siclos, según el siclo del santuario. 86 Doce incensarios de oro, llenos de perfume, de diez siclos cada incensario, conforme al siclo del santuario, siendo todo el oro de los incensarios ciento veinte siclos.

Además se requieren ofrendas voluntarias:

Éxodo 25, 1 Yahveh habló a Moisés, diciendo: 2 «Di a los hijos de Israel que recojan para mí una ofrenda; de todo hombre a quien su corazón mueva a genero-

72 James George Frazer, op. cit., p. 558. 
sidad recogeréis ofrenda para mí. 3 Esta es la ofrenda que habréis de recoger de ellos: oro, plata y bronce; 4 púrpura violácea y púrpura escarlata y carmesí, y lino fino y pelo de cabra; 5 pieles de carneros teñidas de rojo, pieles de tajas y maderas de acacia; 6 aceite para la lámpara, aromas para el óleo de la unción y para el incienso perfumado; 7 piedras de ónice y piedras de engaste para el efod y para el pectoral. $8 \mathrm{Y}$ hazme un santuario para que habite en medio de ellos.

La generosidad del pueblo fue tal que superó las necesidades:

Éxodo 36, 4 [...] todos los peritos que ejecutaban las distintas obras del santuario vinieron cada uno desde su respectiva labor que estaba ejecutando, 5 y hablaron a Moisés para decir: "Las gentes se exceden trayendo más de lo que precisan los trabajos para la obra que Yahveh mando ejecutar" 6 [...] y se ordenó al pueblo se abstuviera de aportar nada.

Después de cada victoria militar se estableció la costumbre de ofrecer el botín como ofrenda voluntaria a Yahveh, aunque, como se recordará, buena parte de la joyería y orfebrería estaba relacionada con las prácticas idolátricas, la magia o la superstición, con lo cual su ofrenda podría resultar contraproducente. Pero, si exceptuamos situaciones extremas, como las destrucciones de algunos ídolos vistas más arriba, pronto se establece una norma o ley para poder purificar las piezas obtenidas en botín, una parte del cual corresponde a Yahveh, o a los levitas (la casta sacerdotal):

Números 31, $21 \mathrm{El}$ sacerdote Elazar dijo a los guerreros que habían ido al combate: «Esta es la prescripción legal que Yahveh ha ordenado a Moisés: $22 \mathrm{El}$ oro, la plata, el bronce, el hierro, el estaño y el plomo 23 todo lo que resiste al fuego, lo haréis pasar por fuego y será puro, sin embargo habrá de ser purificado además por el agua lustral. Y todo lo que no aguanta el fuego lo pasareis por el agua [...] 48 Después acercáronse a Moisés los jefes de las unidades militares [...] 50 En consecuencia, presentamos cada uno como ofrenda a Yahveh lo que apresó en objetos de oro: brazaletes, ajorcas, anillos, arracadas y collares con objeto de expiar por nuestras personas ante Yahveh" 51 Moisés y el sacerdote Elazar aceptaron de ellos el oro: toda suerte de objetos artísticamente trabajados. $52 \mathrm{Y}$ todo el oro de la terumá que elevaron a Yahveh de parte de los kiliarcas y los centuriones, fue dieciséis mil setecientos cincuenta siclos. 53 Los simples combatientes habían pillado cada uno para sí. 54 Y Moisés y el sacerdote Elazar tomaron el oro de los kiliarcas y los centuriones y lo llevaron a la tienda de reunión como recuerdo de los hijos de Israel ante Yahveh.

Números 16, 16 Y Moisés dijo a Core: "Mañana presentaos tu y toda tu facción delante de Yahveh; tu, ella y Aarón. 17 Y tomad cada uno vuestro incensario, en el que pondréis incienso [...] 38 Los incensarios de esos que se han acarreado la muerte con su pecado los transformareis en láminas delgadas para recubrir el altar, porque se los presentó ante Yahveh y están santificados [...] (eran de bronce).

2 Samuel 8, 7 Apoderóse David de los escudos de oro que llevaban encima los súbditos de Hadadézer y los trajo a Jerusalén. [...] 10 [...] (Jorám) era portador de 
vasos de plata, oro y cobre. $11 \mathrm{El}$ rey David los consagró también a Yahveh con la plata y el oro que había recogido de todas las naciones sojuzgadas:

Josué 6 [Toma de Jericól, 18 Vosotros, en verdad, guardaos bien de lo consagrado al exterminio, no sea que, llevados de la codicia, cojáis de lo dado al anatema, expongáis a maldición al real de Israel y le acarréis la desgracia. 19. Toda la plata, el oro y objetos de cobre y hierro serán consagrados a Yahveh, ingresando en el tesoro de Éstew.

La conducta de Akán, ocultando para sí parte del botín provocó el castigo divino haciendo que los israelitas perdieran la batalla contra la ciudad de Haai, y siendo el mismo posteriormente lapidado:

Josué 7, 21 Vi entre el botín un manto hermoso de Sinar, doscientos siclos de plata y un lingote de oro de cincuenta siclos de peso, y, codicioso de ellos, los cogí, y he aquí que están escondidos en la tierra en medio de mi tienda, hallándose el dinero debajo del manto [...] 23 Cogiéronlos de en medio de la tienda y se los llevaron a Josué y todos los israelitas, y los depositaron ante Yahveh [...] 25 [...] Y todo Israel lo apedreó y después lo quemaron en la hoguera, además de lapidarlos.

La toma de Jerusalén, deportando a los judíos a Babilonia y saqueando y destruyendo el primer templo, marca un cambio de periodo en la historia israelita. Su reconstrucción y la restitución del ajuar robado, serán otras de las ocupaciones y preocupaciones principales, no sólo de los judíos, sino también de algunos reyes a los que quedan sometidos y que pretenden granjearse a sus nuevos súbditos:

Esdras 1, 2 "Así dice Ciro, rey de Persia: Todos los reinos de la tierra me ha dado Yahveh, Dios del cielo, y Él mismo me ha encomendado le edifique una casa en Jerusalén, de Judá [...] $4 \mathrm{Y}$ a todo el resto [del pueblo], en cualquier sitio donde more, asístanle los hombres de su lugar con plata, oro, bienes y ganado, además de los donativos voluntarios para la casa de Yahveh que está en Jerusalén " [...] 7 Y el rey Ciro sacó los objetos de la casa de Yahveh que Nabucodonosor había llevado de Jerusalén y colocado en el templo de su dios. 8 Sacólos, pues, Ciro, rey de Persia, por medio de Mitrídates, el tesorero, y los entregó en manos de Sesbassar, príncipe de Judá. 9 El número de ellos es el siguiente: copas de oro, treinta; copas de plata, mil; cuchillos sagrados, veintinueve; vasos de oro, treinta; 10 vasos de plata de segundo orden, cuatrocientos diez; otros utensilios, mil. 11 El total de los objetos de oro y plata eran cinco mil cuatrocientos.

Esdras 2, 68 Algunos de los cabezas de familia, al llegar a la casa de Yahveh, en Jerusalén, ofrecieron espontáneamente donativos para la casa de Dios, con objeto de reedificarla en su emplazamiento. 69 Con arreglo a sus fuerzas dieron al tesoro de la obra sesenta y un mil dáricos de oro, cinco mil minas de plata y cien túnicas sacerdotales. 


\section{LA EDAD DE ORO}

Los reinados de David y especialmente el de su hijo, Salomón, con toda justeza se han denominado la Edad de Oro de la historia israelita y no deja de ser significativo que se emplee el término Edad del Oro como sinónimo de periodo culminante. Ya casi terminada la conquista de la Tierra Prometida, con estos reyes, se vive una monarquía unificada que alcanza, gracias a las relaciones comerciales y a los tributos de otros pueblos, un esplendor y renombre, característico del los imperios de la antigüedad, y no equiparable a ningún otro momento en el devenir histórico posterior. A ello contribuyó, al inicio de la Edad del Hierro, 1200-1000, el colapso de los grandes imperios: egipcio, babilónico, asirio e hittita y el advenimiento de los pueblos del mar, entre los que estaban los filisteos, mientras que, en la costa, las ciudades fenicias crecen en importancia. El territorio en que se asientan los judíos, sobre todo la región de Judá al sur, controla grandes secciones de la costa, y la región alta de los reyes de Transjordania, principal ruta del comercio egipcio y mesopotámico ${ }^{73}$. Si hay algo que señalaba a las potencias del mundo Antiguo era su gran desarrollo en la joyería y orfebrería. Ya hemos hecho muchas menciones sobre las riquezas acumuladas por Salomón y la magnificencia de todas sus estancias y ajuares, pero los relatos sobre su reinado, superan y añaden otros datos, como el establecimiento de relaciones comerciales, el único sistema que nos restaba por tratar para la obtención de las materias primas empleadas en la joyería y orfebrería y, sobre todo, en un tono totalmente legendario, nos sumergen en una poderosa sociedad desbordada por el lujo y la riqueza. Las referencias a las relaciones comerciales establecidas con los fenicios, a los que también se acude para la provisión de hábiles artesanos son numerosas y significativas:

2 Crónicas 9, 10 Los súbditos de Juram y los súbditos de Salomón que traían oro de Ofir, trajeron también ricas maderas y piedras preciosas [...] $13 \mathrm{El}$ peso del oro que llegaba a Salomón cada año era de seiscientos sesenta y seis talentos, $14 \sin$ contar lo que solían traer los traficantes y los mercaderes; [...] 21 Porque el rey poseía naves que iban a Tarsis con los súbditos de Juram, y una vez cada tres años venían los navíos de Tarsis, trayendo oro, plata, marfil, monos y pavos reales. 22 De esta suerte el rey Salomón superó a todos los reyes de la tierra en riqueza y sabiduría. [...] 26 Dominaba a todos los reyes, desde el río [Eufrates] hasta el país de los filisteos y hasta la frontera de Egipto.

Ezequiel 27, 12 Tarsis comerciaba contigo por la abundancia de toda tu riqueza: plata, hierro, estaño y plomo daban por tus mercaderías [...] 15 [...] muchas islas

73 Bradford D. KelleHER, op. cit. 
tenían comercio en servicio tuyo, portándote como tributo colmillos de marfil y ébano. 16 Edom comerciaba contigo por la multitud de tus productos: rubies, púrpura roja, recamados, lino fino, corales y carbunclos daban por tus mercaderías [...] 22 Los mercaderes de Sebá y Ramá comerciaban contigo; el más delicado bálsamo y toda clase de piedras preciosas y oro daban por tus mercaderías. [...] 25 Las naves de Tarsis te transportaban tus mercancías de cambio.

El incremento de la riqueza y el volumen de posesión de metales nobles y piedras preciosas no se restringió a las arcas reales, sino que alcanzó a toda la sociedad:

1 Reyes 10, $27 \mathrm{El}$ monarca logró que la plata fuera en Jerusalén por su abundancia como las piedras, y los cedros como los sicómoros que crecen en la plana. 2 Crónicas 9, 20 [...] De la plata no se hacía estimación alguna en los días de Salomón.

En torno al templo de Salomón, para su construcción y equipamiento es donde se mueven mayor cantidad de tesoros. Ya su padre David comenzó a acopiar los materiales y artífices que edificarían el edificio y su ajuar:

1 Crónicas 22, 14 He aquí que yo, en medio de mi penuria, he preparado para la casa de Yahveh oro en cantidad de cien mil talentos, plata en un millón de talentos y cobre y hierro sin peso calculable, dada su abundancia. También he dispuesto maderas y piedras; y tu podrás añadir sobre ello. 15 Tienes contigo obreros en abundancia: canteros, artífices en madera y en piedras y toda suerte de artistas en cualquier género de trabajos. 16 De oro, plata, cobre y hierro, no hay numero. ¡Disponte, pues, date a la obra y Yahveh sea contigo!n

1 Crónicas 28, 15 asimismo, para los candelabros áureos y sus lámparas, el oro correspondiente al peso de cada uno de los candelabros y sus lámparas, y para los candelabros de plata, la plata [...] con arreglo al servicio a que cada candelabro se destinaba; 16 también por peso el oro necesario para cada una de las mesas de la proposición, y la plata para las mesas de plata; y oro purísimo para tenedores, aspersorios y jarras, y para las copas de oro, el peso correspondiente para cada copa, y para las copas de plata el peso de plata correspondiente a cada una; 18 y para el altar del incienso el peso correspondiente de oro acendrado; y el diseño de la carroza, o sea los querubines en oro, que, desplegadas las alas, cubrieran el arca de la alianza de Yahveh [...]

20 Y añadió David a Salomón, su hijo, "Cobra esfuerzo y ten ánimo, y ponte a la obra, no temas ni desmayes porque Yahveh Elohim, mi Dios, está contigo; no te dejará ni te desamparará hasta acabar toda la obra para el culto de la casa de Yahveh.

También, desde los primeros momentos se hizo necesario designar a unos guardianes o custodiadores para salvaguardar las riquezas acopiadas para el templo y a otros cargos para su buen gobierno: 
1 Crónicas 26, 20 Los levitas, estaban al frente de los tesoros de la casa de Dios y de los tesoros de las cosas consagradas [...] 24 Subael, hijo de Guersom, hijo de Moisés, era prefecto de los tesoros. $25 \mathrm{Y}$ eran sus hermanos, por Eliézer, cuyo hijo fue Rejabyabu, cuyo hijo fue Isaías, cuyo hijo fue Jorám, cuyo hijo fue Zikrí, cuyo hijo fue Selomit: 26 este Selomit y sus hermanos estaban encargados de todos los tesoros de las cosas sagradas que habían consagrado el rey David, los jefes de las casas patriarcales, los kiliarcas, los centuriones y los jefes del ejército; 27 habíanlo consagrado de los obtenido en las guerras y del botín para restaurar la casa de Yahveh. 28 Asimismo, todo lo que habían consagrado Samuel, el vidente; Saúl, hijo de Quis, Abner, hijo de Ner y Joab, hijo de Seruyá: todo estaba a cargo de Selomit y sus hermanos.

Las detalladas y precisas descripciones sobre la construcción del templo, para cuyo diseño Salomón pidió asesoramiento y artesanos a Juram, rey de Tiro, (2 Crónicas 2 ) nos dibujan un lujosísimo edificio ajustado a los prototipos de los palacios fenicios, con tal cúmulo de oro, plata y piedras preciosas que resulta difícil imaginar; por supuesto nada semejante ha llegado hasta nuestro días. Muchos son los dibujos a modo de reconstrucciones arquitectónicas realizadas a partir de las referencias bíblicas, pero en ellas, los detalles que aquí nos interesan (empleo de metales nobles y piedras preciosas) se pierden, por lo que no resultará reiterativo reproducir algunos de los párrafos dedicados al tema:

2 Crónicas 3, 4 [...] la longitud correspondiente a la anchura de la casa, era de veinte, y su altura veinte codos: y lo revistió interiormente de oro puro. 5 Asimismo recubrió la casa mayor de madera de ciprés, y luego la revistió de oro de calidad e insculpió en ella palmas y cadenillas. 6 Además, cubrió la casa de piedras preciosas como ornato y el oro era oro de Parvaim. 7 También revistió de oro la casa, las vigas, los dinteles, las paredes y las puertas: y esculpió querubines sobre las paredes.

8 Hizo luego el edificio del santísimo [...] Recubriólo de oro finísimo, calculado en seiscientos talentos. 9 El peso de la clavazón ascendía a cincuenta siclos de oro. También revistió de oro las habitaciones superiores. 10 En el edificio del santísimo hizo dos querubines labor de estatuario, y se las recubrió de oro [...] 4, 1 También fabricó un altar de bronce de veinte codos de longitud, veinte de ancho y diez de altura. $2 \mathrm{E}$ hizo el mar de metal fundido de diez codos de un borde al otro, redondo enteramente y de cinco codos de altura [...] 4 Descansaba sobre doce reses vacunas, [...] $5 \mathrm{El}$ grosor del mar era de un palmo y su borde, labrado como el borde de una copa, semejaba una flor de lirio, y tenía cabida tres mil batos. [...]. 6 [...] el mar se reservaba para las abluciones de los sacerdotes.

7 Hizo además diez candelabros de oro de acuerdo con la forma prescrita [...] 8 [...] Y fabricó igualmente cien aspersorios de oro [...] 11 Juram fabricó también las ollas, las paletas y los aspersorios. [...] 16 [...] Todos los objetos hízolos Juram-Abi de cobre bruñido para el rey Salomón con destino a la casa de Yahveh. 17 El rey hízolos fundir en la región del Jordán, [...] 19 Asimismo, Salomón hizo fabricar todos los utensilios que había en la casa de Dios: el altar de oro, las mesas sobre 
las cuales se colocaban los panes de la proposición, 20 los candelabros de oro puro con sus lámparas [...] 21 las flores, las lámparas, las despabiladeras, de oro, todo ello de oro purísimo; y los cuchillos, los aspersorios, las cazuelas, los braserillos, de oro fino, y los quiciales del templo para sus puertas interiores del santísimo, y para las puertas del templo, de acceso al santuario, eran de oro.

Al finalizar nuestro trabajo con las alusiones al reinado de Salomón y a la construcción del primer templo, del que antes mencionamos su destrucción y saqueo, incurrimos en arbitrariedades cronológicas, pero hemos pretendido mantenernos fieles al espíritu que el tema aspira a alcanzar en el Antiguo Testamento. Unas veces valores de intercambio económico, otras símbolos de complejos lenguajes sociales, relativos a estados, clases y etnias; siempre deseadas, carismáticas y poderosas, las joyas son, además, vehículo para la magia y atributo u ofrenda de dioses y reyes, un sinónimo de la riqueza y el bienestar, sólo plenamente culminado en los relatos mítico-legendarios del rey Salomón y la construcción del primer templo.

\section{MATILDE FERNÁNDEZ MONTES \\ Departamento de Antropología Instituto de Filología. CSIC.}

A través del análisis de las referencias a los metales nobles y las piedras preciosas contenidas en el Antiguo Testamento, se trata de estudiar los aspectos mágicos, simbólicos y económicos de la joyería y la orfebrería, tanto masculina y femenina, como la propia de las deidades, incluido Yahveh. El contraste de estos datos con los hallazgos arqueológicos colaborará al mejor conocimiento de la antigua joyería judía.

In analyzing the references to rich metals and precious stones in the Old Testament, the author discusses the magical, symbolic, and economic aspects of jewelry and goldsmith for men, women and the deities, including Yahweh. A comparison with the relevant archaeological findings will facilitate a better understanding of ancient Jewish jewelry. 